\title{
Demand for Annuities: Price Sensitivity, Risk Perceptions, and Knowledge
}

M. MARTIN BOYER

SÉBASTIEN BOX-COUILLARD

PIERRE-CARL MICHAUD 
2018s-33

\section{Demand for Annuities: Price Sensitivity, Risk Perceptions, and Knowledge}

M. Martin Boyer, Sébastien Box-Couillard, Pierre-Carl Michaud

\begin{tabular}{c}
\hline Série Scientifique \\
Scientific Series
\end{tabular}

\section{Montréal \\ Octobre/October 2018}

(C) 2018 M. Martin Boyer, Sébastien Box-Couillard, Pierre-Carl Michaud. Tous droits réservés. All rights reserved. Reproduction partielle permise avec citation du document source, incluant la notice $\mathrm{C}$. Short sections may be quoted without explicit permission, if full credit, including $(\mathcal{C}$ notice, is given to the source.

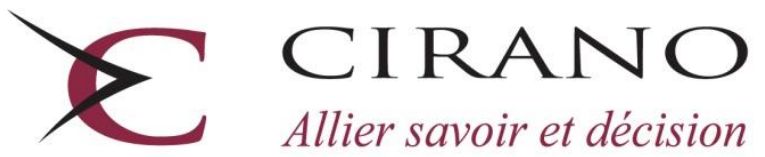

Centre interuniversitaire de recherche en analyse des organisations 


\section{CIRANO}

Le CIRANO est un organisme sans but lucratif constitué en vertu de la Loi des compagnies du Québec. Le financement de son infrastructure et de ses activités de recherche provient des cotisations de ses organisations-membres, d'une subvention d'infrastructure du gouvernement du Québec, de même que des subventions et mandats obtenus par ses équipes de recherche.

CIRANO is a private non-profit organization incorporated under the Quebec Companies Act. Its infrastructure and research activities are funded through fees paid by member organizations, an infrastructure grant from the government of Quebec, and grants and research mandates obtained by its research teams.

\section{Les partenaires du CIRANO}

\section{Partenaires corporatifs}

Autorité des marchés financiers

Banque de développement du Canada

Banque du Canada

Banque Laurentienne du Canada

Banque Nationale du Canada

Bell Canada

BMO Groupe financier

Caisse de dépôt et placement du Québec

Énergir

Hydro-Québec

Innovation, Sciences et Développement économique Canada

Intact Corporation Financière

Investissements PSP

Ministère de l'Économie, de la Science et de l'Innovation

Ministère des Finances du Québec

Mouvement Desjardins

Power Corporation du Canada

Rio Tinto

Ville de Montréal

\section{Partenaires universitaires}

École de technologie supérieure

HEC Montréal

Institut national de la recherche scientifique

Polytechnique Montréal

Université Concordia

Université de Montréal

Université de Sherbrooke

Université du Québec

Université du Québec à Montréal

Université Laval

Université McGill

Le CIRANO collabore avec de nombreux centres et chaires de recherche universitaires dont on peut consulter la liste sur son site web.

Les cahiers de la série scientifique (CS) visent à rendre accessibles des résultats de recherche effectuée au CIRANO afin de susciter échanges et commentaires. Ces cahiers sont écrits dans le style des publications scientifiques. Les idées et les opinions émises sont sous l'unique responsabilité des auteurs et ne représentent pas nécessairement les positions du CIRANO ou de ses partenaires.

This paper presents research carried out at CIRANO and aims at encouraging discussion and comment. The observations and viewpoints expressed are the sole responsibility of the authors. They do not necessarily represent positions of CIRANO or its partners.

ISSN 2292-0838 (en ligne) 


\title{
Demand for Annuities: Price Sensitivity, Risk Perceptions, and Knowledge*
}

\author{
M. Martin Boyer ${ }^{\dagger}$, Sébastien Box-Couillard ${ }^{\ddagger}$, Pierre-Carl Michaud ${ }^{\S}$
}

\begin{abstract}
The demand for voluntary individual lifetime annuities is low. To assess the rea-sons why, we designed a stated-preference experiment where we vary characteristics of annuity contracts to estimate individuals' sensitivity to their value-to-cost ratio, a statistic also known as an annuity's money's worth. Using different measures of longevity risk and survival expectations, including individually tailored estimates from a micro-simulation model and subjective expectations, we investigate how knowledge of the product and mortality risk misperceptions affect the take-up as well as the sensitivity of the demand for annuities. We find that annuities are objectively not priced fairly, although they can appear to be fairly priced given an individual's subjective mortality risk. We also find that demand is somewhat price-inelastic so that, given their current $10 \%$ take-up rate, lowering the price of annuities to fair actuarial levels could increase demand by at most 2 percentage points. Lack of knowledge of annuities explains another 1.2 percentage points. We find limited additional interest for deferred annuities compared to immediate ones although respondents are less price sensitive when evaluating deferred annuities.
\end{abstract}

Keywords: Life annuities' money's worth, Stated preferences, Subjective survival probabilities

JEL Codes: J26, D14, I13

\footnotetext{
* We acknowledge financial support from the Social Science and Humanities Research Council (435-20161109), and we thank the Direction de la recherche at HEC Montr'eal, the Retirement and Savings Institute (ire.hec.ca), as well as CIRANO for their continuing support. We thank David Boisclair for the design of the questionnaire, Moshe Milevsky and CANNEX for providing us with access to pricing data. Boyer holds the Power Corporation of Canada Research Chair in the Finance Department at HEC Montréal, Box-Couillard is a graduate student in the Department of Applied Economics at HEC Montréal, and Michaud holds the Industrielle Alliance Research Chair in the Department of Applied Economics at HEC Montréal.

${ }^{\dagger}$ HEC Montréal and CIRANO

\$EC Montréal

$\S$ HEC Montréal, NBER and CIRANO
} 


\section{Introduction}

In 2017, the Canadian individual life annuity market was worth 16 billion Canadian dollars in benefits and 14 billion Canadian dollars in premiums (CLHIA, 2017). In comparison, total assets from individual registered retirement savings plans (i.e., nonemployer sponsored pension plans) was more than 80 times larger and amounted to the equivalent of 1.15 trillion dollars in 2016. ${ }^{1}$ With respect to registered employer pension plans, the same source evaluated that total assets under management in Canada were 2.1 trillion Canadian dollars in 2016. Another source ${ }^{2}$ suggests that total assets under management in Canada were worth 1.77 trillion USD in 2017. Despite the important increase in total assets in registered saving plans and employer-based pensions plans (23.5\% total growth from 2012 to 2016 in the case of the former, and $31.3 \%$ total growth for the latter), and, more importantly, despite important longevity gains and a continued increase in the population size of potential consumers, the market for individual annuities has hardly grown in size since 2010. In contrast, the total assets of Canadian pension plans has grown at an average annual rate of $6.5 \%$ since 2007. ${ }^{3}$ The lack of growth in the individual annuity market has lead some insurers to announce their decision to exit the market in 2018. This was the case ${ }^{4}$ of Manulife, one of the largest Canadian insurers, which is known in the United States under the name John Hancock. The number of individual lifetime annuity providers in 2018 is less than half of what it was fifteen years ago. ${ }^{5}$

A similar picture emerges from other countries. In Japan, the variable annuity market in the early 2000s was four times larges (at least based on the total premiums paid) than it became ten years later. ${ }^{6}$ In contrast, annuity sales in the United States

\footnotetext{
${ }^{1}$ https: / / www150.statcan.gc.ca/t1/tbl1/en/tv.action?pid=3610057601

${ }^{2}$ www.willistowerswatson.com/-/media/WTW/Images/Press/2018/01/Global-Pension-Asset-Study2018-Japan.pdf.

${ }^{3}$ The cumulative average growth rate in U.S. dollars of Canadian pension total assets is closer to $3.9 \%$ www.willistowerswatson.com op. cit.

${ }^{4}$ Quitting Annuities: Manulife's exit leaves a big gap, Investment Executive, July 2018.

5 www.cannex.com.

${ }^{6}$ See OECD (2016), Life Annuity Products and Their Guarantees, OECD Publishing, Paris,
} 
increased by 24\% between 2013 and 2014 to represent 48 billion U.S. dollars in 2015 . Despite this significant growth, the market for annuities remains marginal compared to the country' total pension assets of 25.4 trillion U.S. dollars in 2017. ${ }^{7}$ With total pension assets of 15.3 trillion dollars in 2007, the U.S. pension system has grown at an average annual rate of $5.2 \%$.

Against the backdrop of this struggling market, the enthusiasm of academics and financial advisors for annuities provides a stark contrast. Yaari (1965) showed that in complete markets with fair pricing, full annuitization is optimal for all risk averse agents. Even in relatively general settings, with imperfect markets, unfair pricing, and bequest motives, partial annuitization remains an optimal rational choice (Brown, 2001; Davidoff et al., 2005). Lifetime annuities provide an excellent hedge against one's longevity risk and are prima facie excellent instruments as insurance for all agents worried about outliving their assets. The fact that individuals do not annuitize much of their wealth (or at least not enough of it) is often called the "annuity puzzle"(Benartzi et al., 2011).

The low take-up rate of individual annuities is a challenge in many countries. Rusconi (2008) writes:

"While the low demand for lifelong annuities has been strongly established in the literature, and is reasonably well understood, it is not clear what ought to be done about it. Annuitization in the world's largest annuity market, the United Kingdom, continues to be broadly unpopular, despite the efforts of policymakers to improve the flexibility granted around the mandatory requirement to convert savings to a lifelong annuity."

One hypothesis that explains this phenomenon is that governments are providing enough financial support to older members of society so that only a few feel the need to annuitize part of their wealth. This is not the case in Canada where the governhttps:/ / doi.org/10.1787/9789264265318-en.

${ }^{7}$ www.willistowerswatson.com op. cit. 
ment's retirement income system provides a generous annuity only to poorer households. This suggests that households, which are not in the lower part of the retirement income distribution, should look favourably at the possibility of partially annuitizing some of their retirement wealth. Despite annuitization being optimal in very diverse settings, annuity choices may be influenced by characteristics of the products that deviate from rational calculations. For example, several studies show that consumers are affected by framing, and that a basic understanding of how annuities work is not widespread (Benartzi et al., 2011; Beshears et al., 2014; Brown et al., 2017). Hence, understanding the demand for annuities and how it reacts to product characteristics is of paramount importance to design and evaluate the effectiveness of public policies geared toward the adequacy of retirement replacement income.

In this paper, we develop a stated-choice experiment designed to elicit preferences for immediate and deferred annuities in Canada. We first evaluate the value of annuities relative to their cost, a ratio known as an annuity's money's worth (Mitchell, 1999). To price the annuities in a Canadian context, we first use pricing data from CANNEX, a quotation service used by brokers, which we combine with individualized longevity risk measures using a micro-simulation approach as well as subjective expectations about longevity. We compare those estimates with those obtained using life-tables by age and sex. We then impose exogenous variations to annuity characteristics and prices offered to our survey participants, which allow us to estimate a flexible regression model linking elicited choice probabilities with the annuities' money's worth, controlling for the individual respondent's stated preferences, socioeconomic characteristics, and knowledge of annuities, inter alia.

Our work builds on the money's worth framework of Mitchell (1999) applied by Milevsky and Shao (2011) for Canada for the period 2000-2009. We deviate from their work by using not only a stated preference approach, but also individual-level objective and subjective survival risk measures to compute the money's worth of the proposed annuities. This allows us to obtain the entire distribution of money's worth, exploiting variation in health and expectations across individuals. We use a stated- 
preference approach, as opposed to a revealed preference approach, because we lack Canadian data on actual annuity purchase decisions. Moreover, the Canadian individual lifetime annuity market does not present much exogenous variation in prices that could be used to investigate how price sensitive consumers are (see Btler et al. (2013) and Chalmers and Reuter (2009) for approaches using actual experiments). Studies investigating the demand for annuities based on stated-preference experiments include Brown et al. (2007), Agnew et al. (2008), and Bateman et al. (2017). An internet-based stated-preference experiment has several advantages. As argued by Louviere et al. (2000), we can generate, for instance, exogenous variations in the characteristics of the product offered and control the choice set faced by consumers. In addition, we can elicit, as suggested by Manski (1999), choice probabilities which provide more information than binary purchase decisions, an approach which is better suited to scenarios that are often incomplete. Finally, we are able to make use of both objective and subjective survival risk which are often not available in other data sources such as data from insurers and may provide additional variation to assess how consumers react to the value of an annuity contract (Hurd, 2009).

We find that annuity pricing is unfair when assuming reasonable discount rates and objective survival probabilities. In particular, using personalized objective longevity risk measures, we find that annuity contracts provide, in terms of expected present value, 0.84 dollar for each dollar of premium paid, a result that is similar to what Milevsky and Shao (2011) found in Canada for the period 2000-2009. Using prospective life-tables from Statistics Canada, annuity contracts provide, in expectation, 0.90 dollar for each dollar of premium. The ratio of value-to-price grows smaller the older is the individual purchasing annuities to hedge his or her longevity risk. The ratio is also smaller for individuals who have less than a high school education, lower income, and lower wealth and savings. Unfair pricing is not a sufficient explanation for the low demand for annuities. After all, insurers must incur operating expenses that must be covered by premiums. What is more interesting about our results is that annuities are perceived as fairly priced with a money's worth equal to one when we 
use the individuals' subjective survival risk instead of the objective measures calculated based on prospective life-tables from Statistics Canada. Hence, longevity risk misperceptions cannot explain the low demand for annuities.

When we regress choice probabilities on money's worth, we find that individuals respond to changes in the value of the annuities offered to them. We find their preferences to be price responsive but relatively inelastic (elasticity ranges from 0.36 using subjective mortality risk to 0.82 using life-table risk). While pricing is unfair, correcting pricing would only lead to an increase in demand of roughly 2 percentage points. We further find that individuals with a better understanding of annuities tend to purchase more of them. Although one could conclude that financial education could increae the take-up rate of annuities, we find that a better awareness of annuities would increase demand by only 1.2 percentage points using our baseline specification.

The paper is structured as follows. Section 2 presents the data we collected from our panel of online respondents. In Section 3 we present evidence on the survey respondents' knowledge of annuities, or lack thereof, as well as the valuation framework we shall use to examine individual lifetime annuities. Section 4 presents the stated-choice experiment we conducted, whereas Section 5 provides the econometric model and methodology that is appropriate in our context. Results are presented and analyzed in Section 6. Finally, Section 7 concludes.

\section{Data}

As outlined previously, two methods can be used to obtain an estimate for the price elasticity of demand for annuities. The first is a natural experiment, where the exogenous price variation usually comes from a change in the regulatory environment. The second method, which is employed here, is to survey individuals' willingness to buy the product at different price levels. To our knowledge, this type of survey has never been conducted in Canada to examine the demand for annuity products. 
We partnered with AskingCanadians, ${ }^{8}$ which is a marketing research firm that designs and implements online surveys, in order to field a survey and conduct our experiment. Members of AskingCanadians' panel answer surveys for which they receive points they can redeem through various loyalty programs such as Aeroplan, PetroCanada, Hudson's Bay, and Via Rail. In June 2017, 3000 randomly chosen Canadians between the ages of 55 and 75 living in British Columbia, Ontario or Quebec (1/3 from each province) answered the survey. Half of the respondents came from the metropolitan areas of Vancouver, Toronto, and Montreal. ${ }^{9}$ We selected the age range of 55 to75 to represents the age at which most individuals would consider purchasing an annuity.

Because answering this survey required Internet access, it is not perfectly representative of the Canadian population. This is mostly seen in the educational attainment of respondents. The divergence is especially apparent in the tails of the distribution as there are less very poorly educated (less than high school) and more highly educated (university) individuals in the survey than in the Canadian population as a whole. Our survey also over-weighs metropolitan areas. We stratify by age, gender, province and education and re-weigh the data using the 2010 Canadian Community Health Survey, a nationally representative survey. When presenting descriptive statistics, we use these weights. We will not weight the regressions since the variables we examine are already taking into account the representative survey wieghts.

The questionnaire is composed of five sections which are relevant for the study of the demand for annuities ${ }^{10}$ :

1. Sociodemographic background, including education, income, health, marital status, number of children, retirement status, and access to a pension plan;

\footnotetext{
${ }^{8}$ www.askingcanadians.com

${ }^{9}$ This condicion was included because a sub-component of the survey focused on housing and insurance products aimed to extract home equity to finance current spending. We reweighted all survey answers to reflect the actual weight of cities according to the 2010 Canadian Community Health Survey.

${ }^{10}$ The full questionnaire can be found in the appendix. The two sections of the internet-based questionnaire that are not relevant to the current study are those related to reverse mortgages and the value of housing.
} 
2. Opinions and perceptions on bequest motives, chances of living to 85 , riskaversion, and the role of family in retirement;

3. Financial literacy, such as compound interest and inflation, and knowledge, such as probabilities;

4. Knowledge of annuities;

5. Preference for annuities using scenarios whereby individuals are asked to evaluate, on a scale of $0-100$, the probability of buying the annuity product presented to them.

\section{Annuity Design and Valuation}

Annuities are some of the simplest financial instruments that exist. They offer a stream of (generally) fixed cash flows for a given period time. Mathematically, from basic finance text books, the present value of a plain vanilla annuity, which pays fixed amount $A$ per period for $N$ periods starting one period from today is given by

$$
P V(A, 0)=\sum_{t=1}^{N} \frac{A}{(1+r)^{t}}=A\left[\frac{1-(1+r)^{-} N}{r}\right]
$$

where $r$ is the appropriate discount rate that reflects the risk of this cash flow. This plain vanilla annuity is also known as an immediate annuity. If the first annuity payment is delayed for $M$ periods (so that the payments start $M+1$ periods from today), then the present value of this deferred annuity is equal to

$$
P V(A, M)=\frac{1}{(1+r)^{M}} \sum_{t=1}^{N} \frac{A}{(1+r)^{t}}=\frac{A}{(1+r)^{M}}\left[\frac{1-(1+r)^{-} N}{r}\right] .
$$

The difference between traditional annuities and lifetime annuities comes from the fact that the last payment is associated with an annuitant's death rather than some arbitrary period $N$. This means that, for a given group of individuals, the expected present value of the plain annuity (or of the deferred annuity) is reduced by the 
group's survival probability curve, which can be defined as the probability of surviving to age $a+t$ given survival to age $a$. Although there are many types of lifetime annuity products in the market place (de-escalating, advanced life deferred, enhanced, inflation indexed, participating, variable to name a few), the most common in most OECD countries ${ }^{11}$ remain the fixed lifetime annuity and the deferred lifetime annuity products. In Canada, in particular, the most common product is the Individual immediate fixed payment annuity. This product, which is often provided by Canadian insurers in an account which is segregated from the insurer's general funds, essentially behaves as a plain vanilla annuity, with the survival probability provison. We will be concentrating on these simpler products in our study of the stated-demand for annuities.

\subsection{Knowledge}

We asked respondents whether they had purchased an annuity. In Table 1, we find that roughly one of out ten respondents (10.7\%) report having an annuity while $78 \%$ do not have an annuity. Another $11.4 \%$ do not know whether or not they one purchased or currently have an annuity. Hence, the take-up of annuities among respondents aged between 55 and 75 is rather low compared to other insurance products such as life insurance. Table 2 provides weighted descriptive statistics with respect to the entire sample of respondents. We note, in particular, that although one third of respondents came from each of the three largest Canadian provinces, the averages of the stratefied samples are different as they take into account the demographics of each province and the socioeconomic composition of the Canada population. As a result, $18.0 \%$ of weighted respondents live in British Columbia, $48.7 \%$ live in Ontario, and the balance of $33.3 \%$ live in Quebec.

Knowledge of annuities is higher among those with annuities. Close to $28 \%$ of respondents who own an annuity report they know a lot compared to $12.4 \%$ among

\footnotetext{
${ }^{11}$ See Table 2.1 in OECD (2016), Life Annuity Products and Their Guarantees, OECD Publishing, Paris, https://doi.org/10.1787/9789264265318-en page 24.
} 
those who did not purchased an annuity. Interestingly, the fraction of respondents reporting no knowledge of annuities is low, even among those without an annuity $(24.7 \%)$.

We find that there is a range of reasons reported for not having an annuity. Three reasons stand out: 1- never offered or thought about (19.7\%) or not knowing what annuities are (9\%), 2- insufficient savings (17.4\%), and 3- no need (21.3\%). The group of individuals who report having never been offered or thought about an annuity is in part composed of individuals who reported no knowledge of annuities. This group of individuals is otherwise quite heterogeneous on other dimensions. Among respondents who report not having sufficient savings to acquire annuities, only $23 \%$ report having more than $50,000 \$$ in savings accumulated compared to $60 \%$ among those without an annuity but who reported another reason ( $\mathrm{t}$-stat of difference = 14.24 , p-value $=0.000)$. Hence, a significant fraction of those who do not own an annuity have limited resources available. Among respondents who feel they do not need an annuity contract, we find that, compared to the rest of the sample, they are disproportionately more likely to have access to an employer-provided pension plan $(\mathrm{t}=6.17, p<0.001)$ and have higher earnings $(\mathrm{t}=-3.99, \mathrm{p}=0.000)$. Only $9.2 \%$ of respondents without an annuity report that pricing is an issue (Bad value for money).

Table 2 presents basic demographic characteristics of annuitants and non-annuitants. Both groups of respondents have approximately the same education levels and similar income levels. Annuitants are slightly more likely to be married and to have children than non-annuitants. Annuitants do have higher median savings, but lower mean savings, which is consistent with the fact that purchasing an annuity requires a significant amount of accumulated savings. The mean projected income at retirement is only slightly higher among annuitants. Finally, respondents with annuities are more likely to be retired and to have contributed to an employer-provided pension plan. 


\subsection{Calculating an Annuity Contract's Money's Worth}

One reason why the pricing might reduce the demand for individual annuities below its social optimum in the Canadian market place (and elsewhere in the OECD) is that annuities are not fairly priced neither in an actuarial sense nor from an individual's perspective. Unfair pricing in an actuarial sense reflects the fact that annuity providers face operational costs (such as rent, salaries, commissions and other overhead costs) and a profit margin, all of which must be reflected in the price of the annuity contract. At the same time, annuity providers are able to keep the excess investment income they made with the annuitants' premium. Subjective unfair pricing comes from various sources, which are specific to an individual, such as one's perceived mortality risk. If, for instance, a respondent perceives his or her mortality risk as higher than what pricing of annuities has been based on, then an annuity's money's worth, which is calculated as the expected discounted payout value (EDPV) divided by the premium paid $(P)$, or $M W=\frac{E D P V}{P}$, could be much less than unity even if the premium was fair by actuarial standards.

There are two key ingredients to computing the expected present value of the annuity: the interest rate used to discount the cash flows, and the mortality risk to adjust for the fact that not every individual will live to the maximum possible age. The $E D P V$ of an annuity paying fixed $A$ is given by

$$
E D P V=\sum_{t=1}^{T-a} \frac{s_{a, a+t}}{(1+r)^{t}} A
$$

where $T$ is some arbitrary maximum possible age (say 99 or 125 years old), $s_{a, a+t}$ is the probability of surviving to age $a+t$ given survival to age $a$. This is nothing more than the present value of an annuity corrected for the projected survival rate of an individual (or of a cohort of individuals). We use a common rate of return $(r)$ of $3 \%$, which represents the rate of return on invested savings that can be obtained elsewhere for a similar amount of risk (for example the real rate of return on long-term senior 
unsecured Corporate bonds is close to $4 \%$ in Canada).

\subsubsection{Survival Risk}

For survival risk, we use three sources. First, we make use of prospective survival rates by gender and province produced by Statistics Canada (Bohnert et al., 2015). We merge each respondent with mortality rates by cohort, gender and province. This yields survival rates $\left\{s_{a, a+t}^{C}\left(x_{i}\right)\right\}_{t=1}^{T-a}$, where $x_{i}$ denotes characteristics of the respondent $i$.

Although this allows for good measures of aggregate mortality, it does not account for the fact that respondents differ in terms of predictable mortality risk beyond their province of origin, their age, and their sex. We used a micro-simulation model designed to simulate future health of individuals based on a rich set of demographic and health dimensions (Boisclair et al., 2016). Specifically, we feed into the micro-simulation information about each respondent's current age, gender, education, and their self-reported diagnosis of health conditions (heart disease, diabetes, cancer, lung disease and hypertension). Denote by $x_{i}$ the vector of characteristics used in the micro-simulation model. We run 1000 simulations until death for each respondents. We compute survival rates at each age as the average of those simulations, which yields $\left\{s_{a, a+t}^{O}\left(x_{i}\right)\right\}_{t=1}^{T-a}$. This provides a set of prospective individual mortality risk profiles.

While actual risk is what determines the profitability of insurance contracts from the insurers' perspective, it is subjective risk that determines the choice made by consumers. Hence, subjective expectations about survival are as important to understanding demand as actual risk. As part of the survey, we ask respondents for their subjective probability they will live to age 85 (see Hurd (2009) for a survey of the literature using such measures). We can compare those subjective probabilities with the objective probability of surviving to age 85 from the micro-simulation model. We construct subjective survival curves by making use of the objective risk to age 85 . 
Denote by $s_{a, 85}^{O}\left(x_{i}\right)$ the objective risk of surviving to age 85 , and by $s_{a, 85}^{S}\left(x_{i}\right)$, the subjective risk. By definition $s_{a, 85}^{O}\left(x_{i}\right)=\exp \left(-\Lambda_{a, 85}^{O}\left(x_{i}\right)\right)$ where $\Lambda_{a, 85}^{O}\left(x_{i}\right)$ is the integrated hazard. In our calculations of an individual's subjective probability of surviving to age 85 , we will assume that $s_{a, 85}^{S}\left(x_{i}\right)=\exp \left(-\psi \Lambda_{a, 85}^{O}\left(x_{i}\right)\right)$. We can easily compute $\psi$ by making use of the two data points ${ }^{12}$ at age 85 . We can then reconstruct subjective curves assuming that $\psi$ is a constant across ages for a given individual. There are cases where respondents report they have a 100 percent chance of surviving to age 85. In such cases, and because having a 100 percent probability of reaching 85 years of age implies $\psi=-\infty$, we substituted the 100 percent subjective probability with a value of 99 percent to obtain finite estimates of $\psi$. These subjective survival curves generate additional variation relative to objective survival curves. Fortunately, there is a sizable correlation between the subjective and the objective probability of living ten more years as the Spearman rank correlation between $s_{a, a+10}^{O}\left(x_{i}\right)$ and $s_{a, a+10}^{S}\left(x_{i}\right)$ is 0.373 , which is significant at the better than 0.1 percent level.

Table 3 reports the average remaining life-expectancy of our respondents calculated using the Statistics Canada forecast, the micro-simulation model, and each respondent's subjective expectations. First, we see that a 55 year old female has on average 31.4-31.9 years to live according to Statistics Canada projections. The microsimulation model, which accounts for the current risk composition of that population, yields similar albeit more conservative figures, in particular for Quebec (3 years difference). It still generates higher remaining life expectancy among females. The average subjective remaining life expectancy of our respondents is much more optimistic than what we calculated using the Statistics Canada or the micro-simulation forecasts. There are even cases where, depending on the province and the respondent's age group, some men subjectively believe their life expectancy to be higher than that of women.

\footnotetext{
${ }^{12}$ That is, knowing $s_{a, 85}^{O}\left(x_{i}\right)=\exp \left(-\Lambda_{a, 85}^{O}\left(x_{i}\right)\right)$ and $s_{a, 85}^{S}\left(x_{i}\right)=\exp \left(-\psi \Lambda_{a, 85}^{O}\left(x_{i}\right)\right)$ we can back out $\psi$.
} 


\subsection{Actual Money's Worth Calculations}

We accessed CANNEX, a quotation system for annuities in Canada in June 2017. We considered immediate and deferred life annuities. We obtained quotes by age and gender, on annuity payouts, $A$, and premiums, $P$, to compute money's worth. We used the average payout across quotes from multiple competitors. Table 4 reports average money's worth by gender and age groups for the three longevity risk measures.

We first note in Table 4 that annuities are not priced at actuarial fair levels when using either the micro-simulation survival probabilities or the life-table survival rates of Statistics Canada. As the average money's worth is 0.90 using life-tables and 0.84 using the micro-simulation model, we have that for a premium of $\$ 100$, individuals received an expected present value of the purchased annuity of between $\$ 84$ and $\$ 90$. When we compute the annuities' money's worth using the respondent subjective survival risk, $s_{a, a+t}^{S}\left(x_{i}\right)$, instead of the two more objective measures, $s_{a, a+t}^{O}\left(x_{i}\right)$, annuities appear to be priced quite fairly since we find an average money's worth of 1.00. Our objectively calculated money's worth are quite comparable to what others have found previously for the Canadian experience. For instance OECD (2016) reports ${ }^{13}$ annuities' money's worth for Canada of between 0.85 and 0.90 using a discount rate base on corporate bond returns, and over 1.00 when using the risk free rate of return (see also Milevsky and Shao (2011)).

Interestingly, the money's worth of annuities is decreasing in age and larger for females. Differences across provinces are rather small. However, differences by socioeconomic status are rather large. Those with more than a high school education have money's worth closer to 1 while those with limited education face relatively unfair pricing. Similar differences are observed by savings level and income level. One possibility why pricing may appear unfair is adverse selection. If those purchasing annuities are expected to live longer, fair pricing would be based on their survival prospects and not those in the population. We find some evidence that those who own

\footnotetext{
${ }^{13}$ OECD (2016), Life Annuity Products and Their Guarantees, OECD Publishing, Paris, https:/ / doi.org/10.1787/9789264265318-en.
} 
annuities are positively selected on survival. Controlling for age, those with an annuity have a micro-simulation remaining life expectancy 0.22 years higher $(\mathrm{t}$-stat $=3.28$, p-value $<0.001)$.

Since averages can be deceptive, we report in Figure 1 the distribution of money's worth using both subjective risk and individual objective risks. We see that the distribution of money's worth using subjective risks has much more variance. Almost all respondents have MW less than one using objective risks while this fraction is less than 0.5 using subjective risks. Of course, these estimates are somewhat sensitive to the discount rate used. Using a discount rate of $2 \%$, close to $40 \%$ of respondents have a money's worth larger than 1 using micro-simulation risk (almost zero if discount rate is 3\%). Figure A.1 reports the distribution of money's worth under alternative discount rates.

\section{The Experiment}

We designed an experiment to investigate preference for immediate and deferred annuities as well as price sensitivity. First, all respondents were shown this introductory text with respect to the section in the questionnaire that was related to annuities:

We are going to show you some simple annuities and ask you to rate them. You can assume that the institution offering the annuity will pay the monthly benefit no matter the circumstances. Once you pay the premium, you receive monthly benefits and have nothing else to pay.

Each product has two attributes:

a) a premium you have to pay;

b) a monthly benefit starting at a given age and lasting until death.

The benefit is adjusted for inflation (indexed).

They are then asked:

What are the chances, $0 \%$ meaning no chance and 100\% meaning for sure, that 
you would purchase this product if it were offered to you by [a trusted/an] insur-

ance company ${ }^{14}$ within the next year?

Each scenario is presented in the following manner to the respondent with age $a$, where $P$ represents the premium amount, $a+j$ represents the age at which the benefits come into force and $A$ the monthly benefit (which we convert to annual):

\begin{tabular}{cc}
\hline $\begin{array}{c}\text { When you buy the annuity } \\
\text { You pay } P\end{array}$ & Starting at age $a+j$ \\
& $\begin{array}{c}\text { You receive } A \text { per month until death, } \\
\text { indexed annually for inflation }\end{array}$ \\
\hline
\end{tabular}

Each individual is then presented with five scenarios, which are randomized on three levels: The age at which the first benefit is paid $(a+j)$, the monthly benefit $(A)$ and the load $(\tau)$ on the annuity premium. These values are randomized in the following way:

$j=[1,75-a+1,85-a+1]$ with probability $[2 / 5,2 / 5,1 / 5]$

$s=[\$ 200, \$ 600, \$ 1,000]$ each with probability $1 / 3$

$\tau=[0.5,0.6,0.7, \ldots . .1 .8,1.9,2.0]$ each with probability $1 / 16$

By varying the age at which the annuity starts $(j)$, we are able to study both immediate and deferred annuities. By varying the monthly benefit paid (s), we are able to examine whether the demand for annuities is linear in the quantity. Finally, the variation in $\tau$ provides the exogenous price variation necessary to estimate the price-elasticity of demand.

Letting $\operatorname{EDPV}(A, r, s, j)$ be the expected discounted present value of the benefits (or the actuarial fair premium for the annuity), the premium in the different scenarios, $P$, is obtained using the following formula:

$$
P=\tau \times \operatorname{EDPV}(A, r, s, j)
$$

\footnotetext{
${ }^{14}$ For half the individuals, the word "trusted" was included, but it did no appear for the other half. This is done to test the importance of behavioral factors in decision making. By varying the use of the word "trusted" we are able to study the impact of framing on the annuity purchase decision.
} 
with

$$
\operatorname{EDPV}(A, r, s, j)=A \sum_{t=1}^{T-a} \iota_{a+j, a+t} \frac{s_{a, a+t}}{(1+r)^{t}}
$$

where $a$ represents the age at which annuity payouts begin so that $\iota_{a+j, a+t}$ is equal to one if current age is older than the age at which the annuity starts $(j=1$ for an immediate annuity). The actuarial fair premium $E D P V$ is therefore the expected present value of the annual constant income $A$, given objective survival probability $s_{t}$, and the appropriate discount rate $r .{ }^{15}$ Setting the monthly benefits to $\$ 200, \$ 600$ and $\$ 1000$ (which correspond to annual benefits of $\$ 2,400, \$ 7,200$, and $\$ 12,000$ respectively), we are able to calculate the actuarial fair premium $(E D P V)$ for each of these life annuities. Multiplying the fair premium by a loading factor $\tau$ gives the premium $(P)$, rounded to the nearest $\$ 500$, shown to respondents. ${ }^{16}$

For given values for $P, A$, and $j$, individuals can then express their preference with respect to the contracts offered. Each respondent was presented 5 different randomly drawn scenarios from the triple $(j, s, \tau)$. Coincidentally, the average choice probability across scenarios was $13.1 \%$, which is not far from the fraction of respondents who said they had an annuity $(10.65 \%)$.

\section{Methodology}

There are different routes to studying preferences for annuities. One would be to construct a life-cycle model and map the choice probabilities to the underlying structural parameters of the model. This requires strong assumptions, in particular with respect to each respondent's subjective expectation about the socioeconomic environment they expect in the future. It also requires that we specify a functional form for preferences. Instead, we follow an a-theoretical approach of mapping choice probabilities onto some of the characteristics of the product offered, as well as characteristics

\footnotetext{
${ }^{15}$ We base $s$ on COMPAS (microsimulation) rates, and we set $r$ to a real rate of return of $2 \%$.

${ }^{16}$ See the detailed questionnaire in the paper's appendix for different examples of actuarial premiums showed to respondents
} 
of the respondent. We think this approach is particularly suited to our setting since we can allow for considerable heterogeneity in preferences. We posit the following model for choice probabilities, $C_{i, n}$ :

$$
C_{i, n}=X_{i} \beta+\gamma \log M W_{i, n}+\psi T_{i, n}+\alpha D_{i, n}+\epsilon_{i, n}
$$

for respondent $i$ in scenario $n$. The choice probabilities are assumed to be a function of characteristics of the respondent $X_{i}$, the money's worth of the annuity, $M W_{i, n}$, whether the scenario mentions that the provided is a trusted insurance company $\left(T_{i, n}\right)$ and whether the annuity is deferred $D_{i, n}=1$. We choose a semi-log specification since choice probabilities can be zero. We can compute the price elasticity of demand as $\eta_{M W}=\frac{\hat{\gamma}}{\bar{C}}$ where $\hat{\gamma}$ denotes an estimate of the parameter $\gamma$ and $\bar{C}$ is the average choice probability in the sample. Finally, $\epsilon_{i, n}$ is a disturbance that is assumed orthogonal to all variables, including in particular to $M W_{i, n}$. Given that we randomize some characteristics of the proposed annuities, this assumption is not restrictive. We can estimate parameters of this equation by least squares using clustered standard errors at the respondent's level. This allows for arbitrary correlation across a respondent's responses and heteroscedasticity across respondents.

We first compute the money's worth of each contract for each scenario using microsimulation survival risk and a real disount rate of future cash flows of $2 \%$. Hence, money's worth estimates vary across scenarios but also across respondents for the same draw of the contract parameters. This provides additional variation to help in identifying $\gamma$. We use four different sets of control variables. First, we control for age, gender, education, marital status and province of residence. Second, we control for the financial situation of these respondents (savings, income, home ownership and value of house). Third, we control for preference "shifters" such as risk aversion, belief that sacrificing current consumption to leave money to children is desirable (measure of bequest motives) and belief that the family should take care of sick parents. Lastly, we control for knowledge of annuities in general and for financial literacy in particu- 
lar (whether the respondent could answer three basic questions on inflation, interest compounding and diversification) following the work of Lusardi and Mitchell (2014). Table 5 reports descriptive statistics on the control variables we use.

Equation 3 is restrictive in the sense that it does not allow $\gamma$ to vary across respondents and scenarios. To relax this assumption, we also consider a model where

$$
C_{i, n}=X_{i} \beta+\gamma\left(Z_{i, n}\right) \log M W_{i, n}+\psi T_{i, n}+\alpha D_{i, n}+\epsilon_{i, n}
$$

with $\gamma\left(Z_{i, n}\right)=\gamma_{0}+\sum_{k} \gamma_{k} Z_{i, n, k}$. We vary the vector $Z_{i}$ of dimension $K$ to tease out heterogeneity in the price sensitivity. We consider three sets of characteristics: demographics, product characteristics and knowledge.

\section{Results}

\subsection{Main Specification}

Table 6 reports OLS estimates for the entire sample (column 1), males (column 2) and females (column 3) using survival risk as estimated from the micro-simulation model. The semi-elasticity of choice probabilities to money's worth of an annuity is 0.090 (standard error of 0.006) in the full sample. This translates into an elasticity (at the mean) of 0.68 . Price sensitivity does not vary much by gender as the elasticity is 0.664 for males and 0.714 for females (semi-elasticity of 0.101 for males and 0.0796 for females). Hence, demand is relatively inelastic. On average, respondents report a probability of purchasing an annuity of 0.131 . The average predicted choice probability if everyone had an annuity with a money's worth of one is 0.147 . Therefore, eliminating completely unfair pricing (which would be tantamount to saying that annuity-providers have no operational costs of that their excess investment income exactly offsets those costs) would increase demand by only 1.6 percentage points or $12 \%$. If the money's worth of annuities' was 0.92 instead of 0.84 , then demand would increase by only 0.8 percentage points. 
Demand for annuities, shown in Table 6, is larger among males and decreases with age. It is larger in British Columbia and Ontario than in Quebec, in particular among females. Interestingly, few of the economic variables such as home value, income and savings have an effect on the demand for annuities, contrary to what theory would predict. In the full sample, demand seems to be lower among those with larger income while estimates suggest it might be larger among those with larger savings but only for females. Overall, these effects are very small. Low demand for annuities cannot be explained easily by differences in economic resources.

Those who have a stronger bequest motive are more likely to purchase annuities, which is not what one would expect unless respondents think that their heirs are entitled to the annuity once they die. Risk aversion is negatively correlated with demand for annuities which could be explained by a larger need for precautionary savings. Interestingly, those who think the family should care for aging parents also have a higher demand for annuities which may suggest that their need for liquidity to pay for long-term care is less of a concern.

Product characteristics in the scenarios we presented appear to be connected to demand, albeit in a modest way. First, there is a premium to having a trusted financial institution offer an annuity as demand increases by 1.9 percentage points in the full sample ( $1.7 \%$ for males and $2.3 \%$ for females). This might indicate that reputation effects are important in this market as the consumer sacrifices large amounts of savings against a promise to be paid until death. A consumer therefore relies on the insurer's solvency for what can become decades. This result is in line with existing research that shows how the demand for insurance decreases with increasing default risk, as in Zimmer et al. (2018). Second, we find a small premium for deferred as opposed to immediate annuities. Demand is 0.9 percentage points larger when a deferred annuity is offered, an effect that is mostly found for males. Deferred annuities are often presented as a promising product that combines longevity risk protection at a lower cost than immediate annuities. However, our estimates suggest limited demand for such products. 
We find that no knowledge of annuities prior to taking part in the experiment is associated with much lower demand for annuities. In the full sample, demand is 4.04 percentage points lower among those with no prior knowledge of annuities. This effect is even larger among males ( -5.8 percentage points compared to -3.1 for females). We documented relatively low knowledge of annuities in Table 1. A total of 27.3 percent of respondents respond not knowing about annuities. Hence, the effect of the absence of knowledge among this group on aggregate demand is of 1.2 percentage points.

\subsection{Other Specifications and Price-Elasticity Measures}

\subsubsection{Source of longevity risk}

In Table 7, we assess the robustness of our main results to the source of longevity risk used to construct our estimates of the annuities' money's worth. Column 1 replicates the specification presented in Table 6 using survival probabilities as calculated from a micro-simulation. In column 2, we use survival probabilities taken from Canadian life tables. We find that the semi-elasticity is slightly larger $(0.109$ with a standard error of 0.006) while other parameter estimates are very similar. Finally, column 3 uses subjective risk and reports a smaller semi-elasticity than using objective or life-table risk.

If longevity risk misperceptions (or privately known risk) were the main drivers of our respondents' decision to purchase life annuities, we should expect to see a larger price effect. We do not see much price-elasticity in the demand for annuities, however (see Tables 8 for the elasticity by gender and Table 9 for the elasticity by survival risk perception). One possible interpretation for the low price-elasticity is that respondents have trouble coupling their expectations regarding survival with the valuation of annuities. Another interpretation is that subjective estimates contain a considerable amount of noise. This interpretation is more likely given that we elicit and the estimate the baseline shift in the mortality hazard from one data point (i.e., 
from $s_{a, 85}^{O}\left(x_{i}\right)=\exp \left(-\Lambda_{a, 85}^{O}\left(x_{i}\right)\right)$ and $s_{a, 85}^{S}\left(x_{i}\right)=\exp \left(-\psi \Lambda_{a, 85}^{O}\left(x_{i}\right)\right)$ we can back out $\psi$, which we apply to all survival probabilities, $\left.s_{a, a+t}^{S}\left(x_{i}\right)\right)$. Hence, measurement error may bias the price sensitivity towards zero.

Looking more carefully at the elasticity estimates in Table 9, which differ with respect to the survival probability measures used, we note that the price elasticity of the demand for annuities is much smaller when we use the individuals' subjective survival probability than for the other two objective probabilities. This tells us that if we were to educate our respondents about their true survival probabilities, then their demand for annuities would become much more responsive to the premium.

\subsubsection{Heterogeneity in price sensitivity}

Table 10 presents OLS estimates for the interaction terms in Equation 4. Our results show that there is a certain degree of heterogeneity in price elasticity. Older individuals are less price sensitive, whereas respondents from British Columbia are relatively more price sensitive than those from other provinces. Insurers may already be aware of the fact that price sensitivity decreases with age since we observe that the money's worth of annuities decreases in the age of the respondent (as seen in table 4). Although there is no segmentation in pricing by province, the heterogeneity in the responses we have suggests that insurers could benefit from a greater use of price discrimination. Price sensitivity is decreasing in income and increasing in home value, although the second effect is relatively small.

From a public policy's point of view, as well as from the point of view of marketing annuities in general, the most facinating result that can be observed in the paper's last table is related to the heterogeneity of the price elasticity of deferred versus immediate lifetime annuity. Being presented a deferred annuity (which we denoted $P V(A, M)$ earlier in the paper) results in lower price sensitivity. This result is particularly interesting as it suggests insurers could use product characteristics to price discriminate and charge higher premiums for deferred annuities since they are valued more and 
customers are less price sensitive to them. Currently, the most common annuity product in Canada remains the immediate annuity (which we denoted $P V(A, 0)$ ). By having access to a deferred annuity, asymmetric information cost betweed the annuity provider and consumer would be reduced, and individuals would, perhaps, be able to protect better those years when they no longer have the ability to supplement their retirement income with part-time work.

\section{Conclusion}

Using a stated-preference experiment, this paper examines the demand for individual annuities in Canada. Our results can be summarized along three main themes: 1Product mispricing, 2- Small but non-zero price-elasticity of demand, and 3- Little potential growth in absolute terms, but large in relative terms.

With respect to product mispricing, we calculated the money's worth of different individual annuity products and examined the demand for them. The money's worth of an annuity is calculated as the present value of the stream of benefits it will pay divided by the current price of such a contract. The money's worth thus depends on the discount rate, which is independent of each individual's personal characteristics, and the purchasing individual's survival probability, which is not. We find that, in Canada, individual annuities are very expensive when analyzed through the scope of an individual's objective survival probability. In fact, we find that individual annuities are objectively over-priced between $11 \%$ and $19 \%$, which represent respectively a present value of benefits of $\$ 90$ and $\$ 84$ for an initial price of $\$ 100$. With respect to subjective survival probabilities, however, individual annuities are fairly priced in Canada with a money's worth of 1 .

The difference between the objective and the subjective money's worth explain our second important result, which is that demand for annuities is price responsive but not very elastic. Unsurprisingly given the result from the money's worth experiment, we find a price elasticity of the demand that is much lower using subjective 
mortality risk (an elasticity of -0.33) than using personalized objective risk measures of longevity risk (an elasticity of -0.86).

Despite individual annuities being objectively unfairly priced in Canada, increasing competition in the market place, which would surely reduce the price of such a longevity hedging instrument, could lead to an increase in the number of households and/or individuals purchasing annuities. Our estimate is that the increase in the take-up rate would approximately be around 2 percentage points. Given the current take up rate of $10.65 \%$, a 2 percentage point increase, although small in absolute terms, would represent almost $20 \%$ increase in the number of annuity contracts sold. In contrast, increasing the consumers' knowledge of annuities would increase demand by 1.3 percentage points. Consequently, the potential increase in the number of households that would hedge their longevity risk with annuity products is, in the best possible market conditions, 31\%, although the absolute increase would only be 3.3 percentage points (from a take-up rate of $10.65 \%$ to $13.95 \%$ ).

The 1.3 percentage point increase in the take-up rate associated with larger awareness of Canadians has to be weighted against the decrease in the take-up rate associated with telling Canadians that they over-estimate their survival probability. In contrast to increasing competition in the market place which cannot result in fewer consumers acquiring an annuity contract, education is a double-edge sword that could lead current purchasers of annuities to realize that they are paying too high a price compared to the objective expected present value of the stream of cash flows they are being promised. Moreover, the price-elasticity of individuals would be likely to increase if they were better educated about their survival probability, thus further reducing their willingness to acquire an annuity if these are not fairly priced. 


\section{References}

Agnew, J. R., Anderson, L., Gerlach, J. R., and Szykman, L. R. (2008). Who chooses annuities? an experimental investigation of the role of gender, framing, and defaults. American Economic Review, 98(2):418-22.

Bateman, H., Eckert, C., Iskhakov, F., Louviere, J., Satchell, S., and Thorp, S. (2017). Default and naive diversification heuristics in annuity choice. Australian Journal of Management, 42(1):32-57.

Benartzi, S., Previtero, A., and Thaler, R. (2011). Annuitization puzzles. Journal of Economic Perspectives, 25(4):143-64.

Beshears, J., Choi, J. J., Laibson, D., Madrian, B. C., and Zeldes, S. P. (2014). What makes annuitization more appealing? Journal of Public Economics, 116(C):2-16.

Bohnert, N., Chagnon, J., Coulombe, S., Dion, P., and Martel, L. (2015). Population projections for canada (2013 to 2038): Technical report on methodology and assumptions. (91-620).

Boisclair, D., Cote-Sergent, A., Laliberte-Auger, F., Marchand, S., and Michaud, P.-C. (2016). A health microsimulation model for Quebec and Canada. Technical report, HEC Montreal - CEDIA.

Brown, J., D. Casey, M., and Mitchell, O. (2007). Who values the social security annuity? new evidence on the annuity puzzle. Technical report, NBER.

Brown, J. R. (2001). Private pensions, mortality risk, and the decision to annuitize. Journal of Public Economics, 82(1):29-62.

Brown, J. R., Kapteyn, A., Luttmer, E. F., and Mitchell, O. S. (2017). Cognitive constraints on valuing annuities. Journal of the European Economic Association, 15(2):429462.

Btler, M., Staubli, S., and Zito, M. G. (2013). How much does annuity demand react to a large price change? Scandinavian Journal of Economics, 115(3):808-824.

Chalmers, J. and Reuter, J. (2009). How do retirees value life annuities? evidence from public employees. NBER Working Papers 15608, National Bureau of Economic Research, Inc.

CLHIA (2017). Canadian life and health insurance facts: 2016 edition. Annual fact book, Canadian Life and Health Insurance Association.

Davidoff, T., Brown, J., and Diamond, P. (2005). Annuities and individual welfare. American Economic Review, 95(5):1573-1590.

Hurd, M. D. (2009). Subjective probabilities in household surveys. Annual Review of Economics, 1(1):543-562. 
Louviere, J., Hensher, D., and Swait, J. (2000). Stated choice methods: analysis and application, volume 17 .

Lusardi, A. and Mitchell, O. S. (2014). The Economic Importance of Financial Literacy: Theory and Evidence. Journal of Economic Literature, 52(1):5-44.

Manski, C. F. (1999). Analysis of choice expectations in incomplete scenarios. Journal of Risk and Uncertainty, 19(1):49-66.

Milevsky, M. A. and Shao, L.-W. (2011). Annuities and their derivatives: The recent canadian experience. In Olivia S. Mitchell, John Piggott, N. T., editor, Securing lifelong Retirement Income:Global Annuity Market and Policy, chapter 4, pages 51-62. Oxford University Press, Oxford.

Mitchell, O. (1999). New evidence on the money's worth of individual annuities. American Economic Review, 89(5):1299-1318.

Rusconi, R. (2008). National annuity markets: Features and implications", oecd working papers on insurance and private pensions. Technical Report 24, OECD Working Papers.

Yaari, M. E. (1965). Uncertain Lifetime, Life Insurance, and the Theory of the Consumer. Review of Economic Studies, 32(2):137-150.

Zimmer, A., Grndl, H., Schade, C. D., and Glenzer, F. (2018). An Incentive-Compatible Experiment on Probabilistic Insurance and Implications for an Insurer's Solvency Level. Journal of Risk and Insurance, 85(1):245-273. 


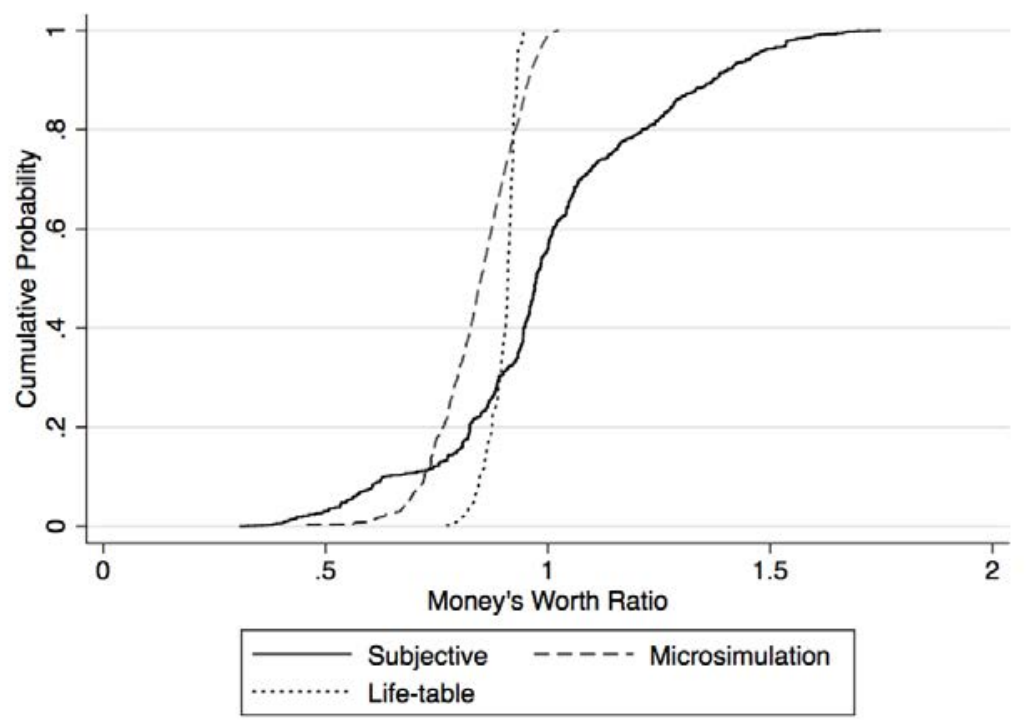

Figure 1: Distribution of Money's Worth of Annuities listed on CANNEX: Life-table, microsimulation and subjective expectations (Survey) 


\begin{tabular}{lrlr}
\hline \hline No Annuity & \multicolumn{2}{c}{ Annuity } \\
\hline & 77.98 & Fraction (\%) & 10.65 \\
\hline Fraction (\%) & & & Knowledge of annuities(\%) \\
Knowledge of annuities (\%) & & A lot & 27.67 \\
\hline A lot & 12.36 & A little & 65.76 \\
A little & 62.93 & None at all & 6.57 \\
None at all & 24.71 & & 67.39 \\
Why don't you have an annuity? (\%) & & How did you come to purchase annuity? (\%) & 21.24 \\
\hline Never offered or thought about & 19.71 & Offered & 11.37 \\
Not yet made decision & 9.43 & Searched myself & \\
Don't have sufficient savings & 17.36 & Other \\
Bad value for money & 9.19 & & \\
Doesn't cover my needs & 8.6 & & \\
No need & 21.28 & & \\
Don't know what it is & 9.01 & & \\
Other & 5.42 & & \\
\hline \hline
\end{tabular}

Table 1: Annuity take-up and annuity knowledge: Statistics weighted. 


\begin{tabular}{|c|c|c|c|}
\hline \multicolumn{2}{|l|}{ No Annuity } & \multicolumn{2}{|l|}{ Annuity } \\
\hline Province of residence $(\%)$ & & Province of residence $(\%)$ & \\
\hline$B C$ & 18.58 & $B C$ & 17.74 \\
\hline Ontario & 50.38 & Ontario & 31.62 \\
\hline Quebec & 31.04 & Quebec & 50.64 \\
\hline Education (\%) & & Education (\%) & \\
\hline Less than HS & 23.95 & Less than HS & 19.2 \\
\hline HS & 31.5 & HS & 36.32 \\
\hline Trade certificate or diploma & 4.46 & Trade certificate or diploma & 4.27 \\
\hline College or Cegep & 13.46 & College or Cegep & 13.94 \\
\hline Some Undergraduate & 4.74 & Some Undergraduate & 5.3 \\
\hline Undergraduate & 13.37 & Undergraduate & 12.21 \\
\hline Graduate & 8.51 & Graduate & 8.77 \\
\hline Marital status (\%) & & Marital status (\%) & \\
\hline Married & 51.77 & Married & 66.09 \\
\hline Common-law & 12.01 & Common-law & 8.83 \\
\hline Widowed & 7.19 & Widowed & 5.01 \\
\hline Separated & 3.19 & Separated & 1.44 \\
\hline Divorced & 13.44 & Divorced & 8.8 \\
\hline Single, never married & 12.4 & Single, never married & 9.84 \\
\hline Children & & Children & \\
\hline Proportion who have children (\%) & 72.56 & Proportion who have children (\%) & 78.73 \\
\hline Mean \# of children & 1.58 & Mean \# of children & 1.78 \\
\hline Income & & Income & \\
\hline Mean household total income & $\$ 91,729$ & Mean household total income & $\$ 86,649$ \\
\hline Median household total income & $\$ 60,000$ & Median household total income & $\$ 63,000$ \\
\hline Mean household total savings & $\$ 265,916$ & Mean household total savings & $\$ 223,482$ \\
\hline Median household total savings & $\$ 72,000$ & Median household total savings & $\$ 100,000$ \\
\hline Retirement & & Retirement & \\
\hline Retired (\%) & 63.66 & Retired (\%) & 74.31 \\
\hline Mean projected income at retirement (\% of current) & 56.71 & Mean projected income at retirement ( $\%$ of current) & 58.86 \\
\hline Employer provided pension plan (\%) & 48.88 & Employer provided pension plan $(\%)$ & 63.43 \\
\hline
\end{tabular}

Table 2: Demographics: This table presents weighted descriptive statistics of demographic variables from our survey. 


\begin{tabular}{|c|c|c|c|c|c|c|c|c|c|c|}
\hline \multirow[b]{2}{*}{ gender } & \multirow{2}{*}{$\begin{array}{l}\text { type } \\
\text { province } \\
\text { age }\end{array}$} & \multicolumn{2}{|c|}{ Subjective } & \multirow[b]{2}{*}{ Quebec } & \multicolumn{3}{|c|}{ Microsimulation } & \multicolumn{2}{|c|}{ Life-Table } & \multirow[b]{2}{*}{ Quebec } \\
\hline & & $\mathrm{BC}$ & Ontario & & $\mathrm{BC}$ & Ontario & Quebec & $\mathrm{BC}$ & Ontario & \\
\hline \multirow[t]{4}{*}{ females } & 55 & 32.9 & 32.0 & 36.2 & 28.7 & 31.0 & 27.9 & 31.9 & 31.6 & 31.4 \\
\hline & 60 & 32.3 & 31.4 & 30.6 & 24.5 & 24.2 & 23.1 & 27.0 & 26.7 & 26.5 \\
\hline & 65 & 25.4 & 31.6 & 26.3 & 20.0 & 18.8 & 19.2 & 22.2 & 21.9 & 21.8 \\
\hline & 75 & 20.4 & 16.0 & 15.3 & 12.0 & 12.0 & 12.2 & 13.5 & 13.3 & 13.3 \\
\hline \multirow[t]{4}{*}{ males } & 55 & 35.8 & 33.9 & 35.7 & 27.7 & 27.5 & 26.6 & 29.7 & 29.2 & 28.8 \\
\hline & 60 & 33.5 & 27.5 & 28.0 & 20.4 & 23.5 & 21.0 & 24.8 & 24.2 & 23.8 \\
\hline & 65 & 21.3 & 19.4 & 26.6 & 14.6 & 16.9 & 19.4 & 20.1 & 19.5 & 19.1 \\
\hline & 75 & 17.9 & 14.3 & 20.3 & 10.7 & 11.2 & 11.0 & 11.7 & 11.3 & 11.0 \\
\hline
\end{tabular}

Table 3: Remaining life expectancies by age, province and gender: according to Life-table (Statistics Canada), microsimulation (COMPAS) and subjective expectations (Survey). 


\begin{tabular}{|c|c|c|c|c|}
\hline & & Subjective & Microsimulation & Life-table \\
\hline \multicolumn{5}{|l|}{ Age } \\
\hline & $55-59$ & 0.98 & 0.88 & 0.92 \\
\hline & $60-64$ & 1.00 & 0.86 & 0.91 \\
\hline & $65-69$ & 1.01 & 0.82 & 0.89 \\
\hline & $70-75$ & 1.03 & 0.77 & 0.85 \\
\hline \multicolumn{5}{|l|}{ Sex } \\
\hline & Female & 0.99 & 0.84 & 0.90 \\
\hline & Male & 1.01 & 0.85 & 0.90 \\
\hline \multicolumn{5}{|c|}{ Province } \\
\hline & British Columbia & 1.00 & 0.82 & 0.91 \\
\hline & Ontario & 0.98 & 0.86 & 0.90 \\
\hline & Quebec & 1.03 & 0.84 & 0.89 \\
\hline \multicolumn{5}{|c|}{ Education } \\
\hline & Less than HS & 1.00 & 0.75 & 0.88 \\
\hline & High School & 0.99 & 0.83 & 0.90 \\
\hline & More than HS & 1.01 & 0.92 & 0.90 \\
\hline \multicolumn{5}{|c|}{ Household income } \\
\hline & 1st tercile & 0.97 & 0.81 & 0.90 \\
\hline & 2nd tercile & 1.00 & 0.84 & 0.90 \\
\hline & 3rd tercile & 1.03 & 0.88 & 0.90 \\
\hline \multicolumn{5}{|c|}{ Savings } \\
\hline & 1st tercile & 0.96 & 0.81 & 0.90 \\
\hline & 2nd tercile & 1.02 & 0.84 & 0.90 \\
\hline & 3rd tercile & 1.02 & 0.87 & 0.90 \\
\hline \multicolumn{5}{|c|}{ Own an annuity? } \\
\hline & Yes & 1.01 & 0.83 & 0.89 \\
\hline & No & 1.00 & 0.85 & 0.90 \\
\hline & Don't know & 0.99 & 0.82 & 0.90 \\
\hline Total & & 1.00 & 0.84 & 0.90 \\
\hline
\end{tabular}

Table 4: Money's worth of annuities listed on CANNEX: microsimulation and subjective expectations (Survey). 


\begin{tabular}{lccccc}
\hline \hline & mean & p50 & sd & min & max \\
\hline age & 63.17 & 63.00 & 5.65 & 55.00 & 75.00 \\
high school & 0.36 & 0.00 & 0.48 & 0.00 & 1.00 \\
college & 0.38 & 0.00 & 0.48 & 0.00 & 1.00 \\
married or common-law & 0.67 & 1.00 & 0.47 & 0.00 & 1.00 \\
British Columbia & 0.18 & 0.00 & 0.38 & 0.00 & 1.00 \\
Ontario & 0.49 & 0.00 & 0.50 & 0.00 & 1.00 \\
home value (thousands) & 380.53 & 275.00 & 433.84 & 0.00 & 2000.00 \\
total income (thousands) & 88.41 & 60.00 & 350.06 & 0.00 & 13000.00 \\
savings (thousands) & 246.27 & 75.00 & 1639.60 & 0.00 & 100000.00 \\
bequest motive & 0.18 & 0.00 & 0.38 & 0.00 & 1.00 \\
risk averse & 0.45 & 0.00 & 0.50 & 0.00 & 1.00 \\
take care & 0.67 & 1.00 & 0.47 & 0.00 & 1.00 \\
no annuity knowledge & 0.27 & 0.00 & 0.45 & 0.00 & 1.00 \\
financial literacy & 0.44 & 0.00 & 0.50 & 0.00 & 1.00 \\
false probabilities & 0.21 & 0.00 & 0.41 & 0.00 & 1.00 \\
\hline \hline
\end{tabular}

Table 5: Descriptive statistics, control variables: Statistics weighted. 


\begin{tabular}{|c|c|c|c|}
\hline & $\begin{array}{l}(1) \\
\text { All }\end{array}$ & $\begin{array}{c}(2) \\
\text { Male }\end{array}$ & $\begin{array}{c}\text { (3) } \\
\text { Female }\end{array}$ \\
\hline log money's worth & $\begin{array}{c}.0903^{* * *} \\
(.0057)\end{array}$ & $\begin{array}{l}.101^{* * *} \\
(.00881)\end{array}$ & $\begin{array}{l}.0801^{* * *} \\
(.00708)\end{array}$ \\
\hline male & $\begin{array}{l}.0252^{* * *} \\
(.00752)\end{array}$ & & \\
\hline age & $\begin{array}{c}-.00202^{* * *} \\
(.000668)\end{array}$ & $\begin{array}{c}-.00196^{*} \\
(.001)\end{array}$ & $\begin{array}{c}-.00221^{* *} \\
(.0009)\end{array}$ \\
\hline high school & $\begin{array}{l}-.0273 \\
(.0212)\end{array}$ & $\begin{array}{l}-.0356 \\
(.0339)\end{array}$ & $\begin{array}{l}-.0179 \\
(.0228)\end{array}$ \\
\hline college & $\begin{array}{l}-.0277 \\
(.0207)\end{array}$ & $\begin{array}{c}-.0382 \\
(.0326)\end{array}$ & $\begin{array}{c}-.0173 \\
(.0228)\end{array}$ \\
\hline married or common-law & $\begin{array}{c}.00383 \\
(.00813)\end{array}$ & $\begin{array}{c}.0142 \\
(.0137)\end{array}$ & $\begin{array}{r}-.00232 \\
(.0101)\end{array}$ \\
\hline British Columbia & $\begin{array}{l}.032^{* * *} \\
(.00905)\end{array}$ & $\begin{array}{l}.0259^{*} \\
(.014)\end{array}$ & $\begin{array}{l}.037^{* * *} \\
(.0113)\end{array}$ \\
\hline Ontario & $\begin{array}{c}.0319^{* * *} \\
(.009)\end{array}$ & $\begin{array}{c}.019 \\
(.0135)\end{array}$ & $\begin{array}{c}.0447^{* * *} \\
(.012)\end{array}$ \\
\hline log homevalue & $\begin{array}{r}-.000852 \\
(.00075)\end{array}$ & $\begin{array}{r}-.000171 \\
(.00115)\end{array}$ & $\begin{array}{l}-.00172^{*} \\
(.000965)\end{array}$ \\
\hline log income & $\begin{array}{l}-.0074^{* *} \\
(.00369)\end{array}$ & $\begin{array}{l}-.0118^{*} \\
(.00677)\end{array}$ & $\begin{array}{l}-.00461 \\
(.00422)\end{array}$ \\
\hline log savings & $\begin{array}{c}.00153 \\
(.000955)\end{array}$ & $\begin{array}{l}.000256 \\
(.00152)\end{array}$ & $\begin{array}{l}.00282^{* *} \\
(.00117)\end{array}$ \\
\hline bequest motive & $\begin{array}{c}.0326^{* * *} \\
(.011)\end{array}$ & $\begin{array}{l}.0347^{* *} \\
(.0146)\end{array}$ & $\begin{array}{l}.0279^{*} \\
(.0167)\end{array}$ \\
\hline risk averse & $\begin{array}{c}-.0332^{* * *} \\
(.00796)\end{array}$ & $\begin{array}{c}-.0365^{* * *} \\
(.0125)\end{array}$ & $\begin{array}{c}-.0308^{* * *} \\
(.0101)\end{array}$ \\
\hline take care & $\begin{array}{c}.0245^{* * *} \\
(.0072)\end{array}$ & $\begin{array}{c}.0291^{* * *} \\
(.0111)\end{array}$ & $\begin{array}{l}.0194^{* *} \\
(.00954)\end{array}$ \\
\hline no annuity knowledge & $\begin{array}{c}-.0405^{* * *} \\
(.00879)\end{array}$ & $\begin{array}{c}-.0579^{* * *} \\
(.015)\end{array}$ & $\begin{array}{c}-.0305^{* * *} \\
(.0108)\end{array}$ \\
\hline financial literacy & $\begin{array}{l}-.00403 \\
(.00775)\end{array}$ & $\begin{array}{c}-.00514 \\
(.0122)\end{array}$ & $\begin{array}{l}-.00296 \\
(.00985)\end{array}$ \\
\hline false probabilities & $\begin{array}{c}.0162 \\
(.0101)\end{array}$ & $\begin{array}{l}.0236 \\
(.018)\end{array}$ & $\begin{array}{c}.011 \\
(.0118)\end{array}$ \\
\hline trusted & $\begin{array}{c}.0184^{* * *} \\
(.007)\end{array}$ & $\begin{array}{l}.0199^{*} \\
(.0106)\end{array}$ & $\begin{array}{c}.019^{* *} \\
(.00916)\end{array}$ \\
\hline deferred & $\begin{array}{l}.00864^{*} \\
(.00446)\end{array}$ & $\begin{array}{c}.0107 \\
(.00699)\end{array}$ & $\begin{array}{c}.0061 \\
(.00554)\end{array}$ \\
\hline $\mathrm{N}$ & 15005 & 7495 & 7510 \\
\hline r2 & .0591 & .0564 & .0542 \\
\hline
\end{tabular}

Standard errors in parentheses

${ }^{*} p<0.1,{ }^{* *} p<0.05,{ }^{* * *} p<0.01$

Table 6: Regression estimates for probability of purchasing annuity contract by gender: Standard errors in parentheses. ${ }^{*} p<0.1,{ }^{* *} p<0.05,{ }^{* *} p<0.01$. 


\begin{tabular}{|c|c|c|c|}
\hline & $\begin{array}{c}(1) \\
\text { Microsimulation }\end{array}$ & $\begin{array}{c}(2) \\
\text { Life-table }\end{array}$ & $\begin{array}{c}\text { (3) } \\
\text { Subjective }\end{array}$ \\
\hline \multirow[t]{2}{*}{ log money's worth } & $.0903^{* * *}$ & $.109^{* * *}$ & $.047^{* * *}$ \\
\hline & $(.0057)$ & $(.00584)$ & $(.00393)$ \\
\hline \multirow[t]{2}{*}{ male } & $.0252^{* * *}$ & $.0274^{* * *}$ & $.029^{* * *}$ \\
\hline & $(.00752)$ & $(.00749)$ & $(.00747)$ \\
\hline \multirow[t]{2}{*}{ age } & $-.00202^{* * *}$ & $-.00184^{* * *}$ & $-.0025^{* * *}$ \\
\hline & $(.000668)$ & $(.000668)$ & $(.000666)$ \\
\hline \multirow[t]{2}{*}{ high school } & -.0273 & -.00683 & -.00547 \\
\hline & $(.0212)$ & $(.0212)$ & $(.0211)$ \\
\hline \multirow[t]{2}{*}{ college } & -.0277 & .0112 & .012 \\
\hline & $(.0207)$ & $(.0208)$ & $(.0207)$ \\
\hline \multirow[t]{2}{*}{ married or common-law } & .00383 & .00525 & .00474 \\
\hline & $(.00813)$ & $(.00813)$ & $(.00811)$ \\
\hline \multirow[t]{2}{*}{ British Columbia } & $.032^{* * *}$ & $.0264^{* * *}$ & $.0345^{* * *}$ \\
\hline & $(.00905)$ & $(.00904)$ & $(.00907)$ \\
\hline \multirow[t]{2}{*}{ Ontario } & $.0319^{* * *}$ & $.0336^{* * *}$ & $.0409^{* * *}$ \\
\hline & $(.009)$ & $(.009)$ & $(.00905)$ \\
\hline \multirow[t]{2}{*}{ log homevalue } & -.000852 & -.000679 & -.000918 \\
\hline & $(.00075)$ & $(.000749)$ & $(.000745)$ \\
\hline \multirow[t]{2}{*}{ log income } & $-.0074^{* *}$ & $-.00724^{* *}$ & $-.00791^{* *}$ \\
\hline & $(.00369)$ & $(.00367)$ & $(.00362)$ \\
\hline \multirow[t]{2}{*}{ log savings } & .00153 & $.00182^{*}$ & $.00162^{*}$ \\
\hline & $(.000955)$ & $(.000957)$ & $(.000946)$ \\
\hline \multirow[t]{2}{*}{ bequest motive } & $.0326^{* * *}$ & $.0328^{* * *}$ & $.0355^{* * *}$ \\
\hline & $(.011)$ & $(.011)$ & $(.011)$ \\
\hline \multirow[t]{2}{*}{ risk averse } & $-.0332^{* * *}$ & $-.0331^{* * *}$ & $-.0308^{* * *}$ \\
\hline & $(.00796)$ & $(.00797)$ & $(.00796)$ \\
\hline \multirow[t]{2}{*}{ take care } & $.0245^{* * *}$ & $.025^{* * *}$ & $.0216^{* * *}$ \\
\hline & $(.0072)$ & $(.0072)$ & $(.00721)$ \\
\hline \multirow[t]{2}{*}{ no annuity knowledge } & $-.0405^{* * *}$ & $-.0408^{* * *}$ & $-.0401^{* * *}$ \\
\hline & $(.00879)$ & $(.00881)$ & $(.00876)$ \\
\hline \multirow[t]{2}{*}{ financial literacy } & -.00403 & -.00336 & -.00325 \\
\hline & $(.00775)$ & $(.00777)$ & $(.00775)$ \\
\hline \multirow[t]{2}{*}{ false probabilities } & .0162 & $.0168^{*}$ & .0149 \\
\hline & $(.0101)$ & $(.0101)$ & $(.01)$ \\
\hline \multirow[t]{2}{*}{ trusted } & $.0184^{* * *}$ & $.0182^{* * *}$ & $.018^{* *}$ \\
\hline & $(.007)$ & $(.00699)$ & $(.00699)$ \\
\hline \multirow[t]{2}{*}{ deferred } & $.00864^{*}$ & -.00227 & -.00357 \\
\hline & $(.00446)$ & $(.00442)$ & $(.00446)$ \\
\hline $\mathrm{N}$ & 15005 & 15005 & 15005 \\
\hline r2 & .0591 & .064 & .0529 \\
\hline
\end{tabular}

Table 7: Regression estimates for probability of purchasing annuity contract using different sources of longevity risk: Standard errors in parentheses. ${ }^{*} p<0.1{ }^{* *} p<0.05,{ }^{* * *}$ $p<0.01$. 


\begin{tabular}{cccc}
\hline \hline & $(1)$ & $(2)$ & $(3)$ \\
& All & Male & Female \\
\hline \hline \multirow{2}{*}{ elasticity } & & & \\
& $.6841^{* * *}$ & $.6641^{* * *}$ & $.7136^{* * *}$ \\
& $(.0432)$ & $(.0578)$ & $(.0635)$ \\
\hline \hline
\end{tabular}

Table 8: Price elasticity estimates: Standard errors in parentheses. ${ }^{*} p<0.1,{ }^{* *} p<0.05$, *** $p<0.01$.

\begin{tabular}{cccc}
\hline \hline & $(1)$ & $(2)$ & $(3)$ \\
& Microsimulation & Life-table & Subjective \\
\hline \multirow{3}{*}{ elasticity } & $.6841^{* * *}$ & $.8232^{* * *}$ & $.3552^{* * *}$ \\
& $(.0432)$ & $(.0443)$ & $(.0298)$ \\
\hline \hline
\end{tabular}

Table 9: Price elasticity estimates: Standard errors in parentheses. ${ }^{*} p<0.1{ }^{* *} p<0.05$, *** $p<0.01$. 


\begin{tabular}{|c|c|}
\hline & $\begin{array}{c}(1) \\
\text { Heterogeneity }\end{array}$ \\
\hline log money's worth & $\begin{array}{l}.249^{* * *} \\
(.0587)\end{array}$ \\
\hline male $=1 \times \log$ money's worth & $\begin{array}{c}.0083 \\
(.00819)\end{array}$ \\
\hline log money's worth $\times$ age & $\begin{array}{l}-.00148^{* *} \\
(.000711)\end{array}$ \\
\hline high school $=1 \times \log$ money's worth & $\begin{array}{l}.00463 \\
(.0137)\end{array}$ \\
\hline college $=1 \times \log$ money's worth & $\begin{array}{l}.00898 \\
(.0135)\end{array}$ \\
\hline Yes $\times \log$ money's worth & $\begin{array}{l}.00374 \\
(.00881)\end{array}$ \\
\hline British Columbia $=1 \times \log$ money's worth & $\begin{array}{c}.0288^{* * *} \\
(.0101)\end{array}$ \\
\hline Ontario $=1 \times \log$ money's worth & $\begin{array}{l}.0197^{* *} \\
(.00998)\end{array}$ \\
\hline $\log$ money's worth $\times \log$ homevalue & $\begin{array}{l}-.00152^{*} \\
(.00081)\end{array}$ \\
\hline $\log$ money's worth $\times \log$ income & $\begin{array}{c}-.00682^{* * *} \\
(.00263)\end{array}$ \\
\hline log money's worth $\times$ log savings & $\begin{array}{l}.000538 \\
(.000849)\end{array}$ \\
\hline bequest motive $=1 \times \log$ money's worth & $\begin{array}{r}-.00116 \\
(.0112)\end{array}$ \\
\hline risk averse $=1 \times \log$ money's worth & $\begin{array}{l}-.0172^{*} \\
(.00904)\end{array}$ \\
\hline take care $=1 \times \log$ money's worth & $\begin{array}{c}.0062 \\
(.00768)\end{array}$ \\
\hline no annuity knowledge $=1 \times \log$ money's worth & $\begin{array}{c}-.0108 \\
(.00922)\end{array}$ \\
\hline financial literacy=1 × log money's worth & $\begin{array}{l}.00991 \\
(.00886)\end{array}$ \\
\hline false probabilities $=1 \times \log$ money's worth & $\begin{array}{l}-.00356 \\
(.0124)\end{array}$ \\
\hline trusted $=1 \times \log$ money's worth & $\begin{array}{l}.00149 \\
(.0077)\end{array}$ \\
\hline deferred $=1 \times \log$ money's worth & $\begin{array}{c}-.0699 * * * \\
(.00731)\end{array}$ \\
\hline $\mathrm{N}$ & 15005 \\
\hline r2 & .064 \\
\hline
\end{tabular}

Table 10: Regression estimates for probability of purchasing annuity contract, interactions only: Standard errors in parentheses. ${ }^{*} p<0.1,{ }^{* *} p<0.05,{ }^{* * *} p<0.01$. 


\section{A Additional Results on Money's Worth}

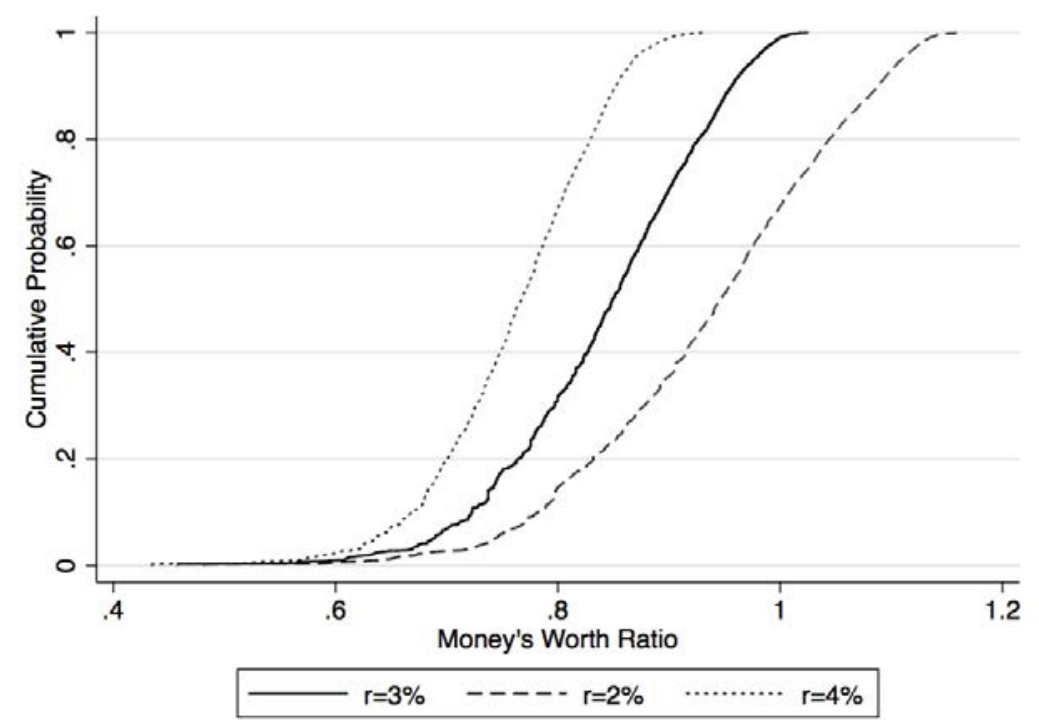

Figure A.1: Distribution of Money's Worth of Annuities listed on CANNEX: Robustness to Discount Rate 
B Questionnaire 


\section{Section 1: Background}

A Are you...?

1.1. Male

1.2. Female

B How old are you?

2.1. Please Enter (terminate if not 55-75 INCLUSIVELY)

[PN: MUST ENTER THE 2 CHARACTERS]

QC. Which province or territory do you live in?

1.1. British Columbia

1.2. Alberta [Screen Out]

1.3. Saskatchewan [Screen Out]

1.4. Manitoba [Screen Out]

1.5. Ontario

1.6. Quebec

1.7. New Brunswick [Screen Out]

1.8. Nova Scotia [Screen Out]

1.9. Prince Edward Island [Screen Out]

1.10. Newfoundland [Screen Out]

1.11. Northwest Territories [Screen Out]

1.12. Nunavut [Screen Out]

1.13. Yukon [Screen Out]

1.14. None of the above [Screen Out]

Q0 Can you please enter the first 3 characters of your postal code? Please type in below [PN: MUST ENTER FIRST 3 CHARACTERS] *FSAs validated with FSA file

Q1 What is the highest degree, certificate or diploma you have obtained?

1 Less than high school diploma or its equivalent

2 High school diploma or a high school equivalency certificate

3 Trade certificate or diploma

4 College, CEGEP or other non-university certificate or diploma (other than trades certificates or diplomas)

5 University certificate or diploma below the bachelor's level

6 Bachelor's degree (e.g. B.A., B.Sc., LL.B.)

7 University degree above the bachelor's level

Q2 What is your marital status?

1 married

2 living common-law

3 widowed

4 separated 
5 divorced

6 single, never married

IF Q2 $==1,2$

Q2a How old is your partner (spouse)?

Numeric $(>0)$

END IF

Q3 Do you have children?

$1 \mathrm{Yes}$

2 No

IF Q3==1 ask Q3b

IF Q3 = 2 skip to Q4

Q3b Have you experienced a loss of a child?

1 Yes

2 No

IF Q3b = 1 ask Q3a

IF $\mathrm{Q} 3 \mathrm{~b}=2$ ask Q3c

Q3a How many of your children are alive today?

Numeric $(>=0)$

Q3c How many children do you have?

Numeric $(>=0)$

END IF

Q4 For 2016, what is your best estimate of the total income received by all members of your household, from all sources, before taxes and deductions?

Numeric $(>0)$

9999999 Don't know or prefer not to say

IF Q4==9999999

Q4a Is it more than $\$ 60,000$ ? 1 Yes 2 No 8888888 Refuse to answer 7777777 Don't know $\mathrm{IF} \mathrm{Q} 4 \mathrm{a}==1$

Q4b Is it less than \$120,000? 1 Yes 2 No 8888888 Refuse to answer 7777777 Don't know

IF $\mathrm{Q} 4 \mathrm{~b}==1$

Q4c Is it more than \$90,000? 1 Yes 2 No 8888888 Refuse to answer 7777777 Don't know

END IF

ELSE IF Q4a==2

Q4d Is it more than \$30,000? 1 Yes 2 No 8888888 Refuse to answer 7777777 Don’t know

END IF

END IF

Q5 Do you consider yourself retired? 
1 Yes

2 No

IF $\mathrm{Q} 5==2$

Q5a What is your best estimate of what total income received by all members of your household will be once you are fully retired, as a fraction of your current income?

Numeric (0\%-200\%)

9999999 Don't know

IF Q5a==9999999

Q5b Is it more than 50\%? 1 Yes 2 No 8888888 Refuse to answer 7777777 Don't know IF $\mathrm{Q} 5 \mathrm{~b}==1$

Q5c Is it less than 75\%? 1 Yes 2 No 8888888 Refuse to answer 7777777 Don't know

IF Q5c $==1$

Q5d Is it more than 62.5\%? 1 Yes 2 No 8888888 Refuse to answer 7777777 Don't know

ELSE IF Q5c $==2$

Q5e Is it less than 87.5\%? 1 Yes 2 No 8888888 Refuse to answer

7777777 Don't know

END IF

ELSE IF Q5b==2

Q5f Is it more than 25\%? 1 Yes 2 No 8888888 Refuse to answer 7777777 Don't know

IF $\mathrm{Q} 5 \mathrm{f}==1$

Q5d Is it more than 37.5\%? 1 Yes 2 No 8888888 Refuse to answer

7777777 Don't know

ELSE IF Q5f $==2$

Q5e Is it less than 12.5\%? 1 Yes 2 No 8888888 Refuse to answer 7777777 Don't know

\section{END IF}

END IF

\section{END IF}

END IF

Q6 Do you own your primary residence?

1 Yes

2 No

IF Q6==1

Q6a Which set of property type best fits your primary residence?

1 Single Family Dwelling / Detached Duplex, Triplex or Quadruplex / Link home / Semi-

Detached.

2 Townhouse, Rowhouse / Fiveplex and Sixplex / Attached Duplex, Triplex or Quadruplex /

Stratified SFD, Bare Land Strata / Semi-Detached Strata Condo / Modular Home

3 Condo-Townhouse / Mobile Home / Condo - Apartment Style

7777777 Don't know

Q7 What is the current market value of your residence?

Numeric $(>0)$

9999999 Don't know or prefer not to say

IF Q7==9999999 
Q7a Is it more than $\$ 300,000$ ? 1 Yes 2 No 8888888 Refuse to answer 7777777 Don’t know IF $\mathrm{Q} 7 \mathrm{a}==1$

Q7b Is it less than $\$ 600,000$ ? 1 Yes 2 No 8888888 Refuse to answer 7777777 Don't know

IF $\mathrm{Q} 7 \mathrm{~b}==1$

Q7c Is it more than $\$ 450,000$ ? 1 Yes 2 No 8888888 Refuse to answer 7777777 Don't know

ELSE IF Q7b $==2$

Q7d Is it less than $\$ 750,000$ ? 1 Yes 2 No 8888888 Refuse to answer 7777777 Don't know

IF Q7d $==2$

Q7e Is it more than $\$ 900,000$ ? 1 Yes 2 No 8888888 Refuse to

END IF answer 7777777 Don't know

END IF

ELSE IF Q7a==2

Q7f Is it more than $\$ 150,000$ ? 1 Yes 2 No 8888888 Refuse to answer 7777777 Don't know

\section{END IF}

END IF

Q8 What proportion of the current market value of your residence do you still owe on your mortgage?

Numeric (0\%-200\%)

9999999 Don't know or prefer not to say

IF Q8 == 9999999

Q8a Is it more than 50\%? 1 Yes 2 No 8888888 Refuse to answer 7777777 Don't know

IF $\mathrm{Q} 8 \mathrm{a}==1$

Q8b Is it less than $75 \%$ ? 1 Yes 2 No 8888888 Refuse to answer 7777777

Don't know

$\mathrm{IF} \mathrm{Q} 8 \mathrm{~b}==1$

Q8c Is it more than 62.5\%? 1 Yes 2 No 8888888 Refuse to answer 7777777 Don't know

ELSE IF Q8b $==2$

Q8d Is it more than 87.5\%? 1 Yes 2 No 8888888 Refuse to answer 7777777 Don't know

END IF

END IF

\section{ELSE IF Q8a $==2$}

Q8e Is it less than $25 \% 1$ Yes 2 No 8888888 Refuse to answer 7777777 Don't know

IF Q8e $==1$

Q8f Is it more than $12.5 \%$ ? 1 Yes 2 No 8888888 Refuse to answer 7777777

Don't know

$$
\text { IF Q8f }==2
$$


Q8g Is it less than 5\%? 1 Yes 2 No 8888888 Refuse to answer 7777777

Don't know

END IF

ELSE IF Q8e $==2$

Q8h Is it more than 37.5\%? 1 Yes 2 No 8888888 Refuse to answer 7777777 Don't know

\section{END IF \\ END IF \\ END IF}

\section{END IF}

Q9 We are interested in your pension plan and its nature, if you have one. Do you currently contribute to, or receive benefits from (in the form of regular payments), an employer-provided pension plan?

1 Yes

2 No

3 Don't Know

IF Q9==1

Q9a Do you agree with the following statement: "I have/expect to have sufficient pension income"?

1 Completely disagree

2 Disagree

3 Somewhat disagree

4 Neither agree nor disagree

5 Somewhat agree

6 Agree

END IF

7 Completely agree

Q10 What is your best estimate of how much you have accumulated in Registered Retirement Savings Plans (RRSPs), Tax-Free Savings Accounts (TFSAs) and other non-employer provided savings accounts?

Numeric

9999999 Don't know or prefer not to say

IF Q10==9999999

Q10a Is it more than \$50,000? 1 Yes 2 No 8888888 Refuse to answer 7777777 Don't know IF Q10a==1

Q10b Is it less than \$200,000? 1 Yes 2 No 8888888 Refuse to answer 7777777 Don't know

ELSE IF Q10a==2

Q10c Is it more than \$10,000? 1 Yes 2 No 8888888 Refuse to answer 7777777 Don’t know

END IF

END IF

Q11 Looking at the following list of health conditions, has a doctor ever said you suffered from:

[Check any of:]

1 Heart disease

2 Stroke 


\section{Lung disease}

4 Diabetes

5 Hypertension

6 Depression or other mental health problems

7 Cancer

8 None of the above

Q12 At the present time, do you smoke cigarettes daily, occasionally or not at all?

1 Daily

2 Occasionally

3 Not at all

IF Q12==1 GOTO Q13

ELSE IF Q12==2,3

Q12a Have you ever smoked cigarettes daily?

$1 \mathrm{Yes}$

2 No

IF Q12a==1 GOTO Q13

ELSE IF Q12a==2

Q12b Have you smoked 100 cigarettes or more in your life?

1 Yes

2 No

IF Q12b==1 GOTO Q13

ELSE IF Q12b==2

Q12c Have you ever smoked a whole cigarette?

1 Yes

2 No

END IF

\section{END IF}

END IF

\section{Section 2: Risk Perception}

Q13 On a scale of 0 to 100 , where 0 is absolutely no chance and 100 is absolutely certain, what do you believe is the percent chance you will live to age 85 or more?

Numeric (0-100)

9999999 Don't know

IF Q2==1,2 \& Q2a $<85$

Q13a On a scale of 0 to 100 , where 0 is absolutely no chance and 100 is absolutely certain, what do you believe is the percent chance your partner (spouse) will live to age 85 or more?

Numeric (0-100)

9999999 Don't know

\section{END IF}

Q14 On a scale of 0 to 100 , where 0 is absolutely no chance and 100 is absolutely certain, what do you believe is the percent chance you will leave a bequest of more than $\$ 10,000$ ?

Numeric (0-100) 
9999999 Don't know

IF Q14 >0 \& Q6 ==1

Q14a How likely is it that your primary residence will play a role in the bequest you plan to leave?

1 Not likely at all

2 Not very likely

3 Somewhat likely

4 Very likely

5 Extremely likely

END IF

Q15 On a scale of 0 to 100 , where 0 is absolutely no chance and 100 is absolutely certain, what do you believe is the percent chance that your family would take up the responsibility of taking care of you if you had important limitations in activities of daily living such as bathing, eating, cleaning?

Numeric (0-100)

9999999 Don't know

Q16 On a scale of 0 to 100 , where 0 is absolutely no chance and 100 is absolutely certain, what do you believe is the percent chance that your family would take care of you financially if you needed financial support?

Numeric (0-100)

9999999 Don't know

IF Q6==1

Q17 Here are three possibilities concerning your future expected residence. On a scale of 0 to 100 , where 0 is absolutely no chance and 100 is absolutely certain, what is the percent chance that each of these possibilities comes true. Given that only one of these possibilities can occur, the sum of the three probabilities must equal 100 .

Q17a I'm going to stay in my current home until I die.

Numeric (0-100)

Q17b I will eventually move from my current home to live in another house or apartment.

Numeric (0 to (100 - Answer Q17a))

Q17c I will eventually move from my current home to live in a long-term care home. Numeric (0 to (100 - Answer Q17a - Answer Q17b))

[NOTE: SUM OF ANSWERS TO Q17a, Q17b AND Q17c MUST EQUAL 100.]

[NOTE: MAKE SURE THE QUESTION IS PROPERLY NUMBERED ON THE SCREEN.]

[NOTE: WOULD IT BE POSSIBLE TO INCLUDE A COUNTER TO LET THE RESPONDENT

KNOW HOW MANY \% LEFT TO FILL IN?]

Q18 Over the next five years, do you think the value of your home will:

1 Increase a lot (greater than $20 \%$ )

2 Increase moderately (between $5 \%$ and 20\%)

3 remain rather stable (between $+5 \%$ and $-5 \%$ )

4 decrease moderately (between $-5 \%$ and $-20 \%$ ) 
5 decrease a lot (less than $-20 \%)$

Q19 Do you agree with the following statement: "House prices can fluctuate a lot"?

1 Completely disagree

2 Disagree

3 Somewhat disagree

4 Neither agree nor disagree

5 Somewhat agree

6 Agree

END IF

7 Completely agree

Q20 Do you agree with the following statements? (Answers: 5 Strongly Agree; 4 Agree; 3 Disagree; 2 Strongly Disagree; 1 Don't know)

Q20a It is the responsibility of the family, when feasible, to take care of elderly parents

Q20b Parents should set aside money to leave to their children or heirs once they die, even when it means somewhat sacrificing their own comfort in retirement

Q20c Children should inherit their parents' family home

Q20d A house is an asset that should only be sold in case of financial hardship

Q20e Being in debt is never a good thing

[NOTE: Make sure the question is properly numbered on the screen.]

[NOTE: Might the scale for each statement be inverted (i.e. "increasing" from left to right)? We leave this with your expertise.]

Q21 Which of the following statements comes closest to describing the amount of financial risk that you are willing to take when you save or make investments?

1 I am willing to take substantial financial risks expecting to earn substantial returns

2 I am willing to take above average financial risks expecting to earn above-average returns

3 I am willing to take average financial risks expecting to earn average returns

4 I am willing to take below average financial risks expecting to earn below-average returns

5 I am not willing to take any risk, knowing I will earn a small but certain return

\section{Section 3: Literacy and Knowledge}

Now we would like to ask some questions about your familiarity and comfort with financial concepts. Please answer these questions the best you can.

Q22 Suppose you have $\$ 100$ in a savings account, the interest rate is $2 \%$ per year and you never withdraw money. After 5 years, how much will you have in this account in total?

1 More than $\$ 110$

2 Exactly $\$ 110$

3 Less than $\$ 110$

4 Don't know

Q23 True or false? You should invest most of your money in a single stock that you select rather than in lots of stocks or in mutual funds.

1 True

2 False 


\section{Don't know}

Q24 Imagine leaving \$1,000 in a savings account that pays 1\% interest and has no charges. Imagine that inflation is running at $2 \%$. Do you think that if you withdraw the money in a year's time you will be able to buy more than, exactly the same as, or less than today with the money in this account?

1 More than today

2 Exactly the same as today

3 Less than today

4 Don't know

Q25 Suppose the chances of someone aged 50 living to age 85 are $60 \%$. What do you think the chances are that this same person will live to age 60 ?

1 Less than $60 \%$

2 Greater than $60 \%$

3 Don't know

\section{Section 4: Annuities}

For the purposes of this section, when we use the term 'annuity', we are referring to a financial product that guarantees you a regular payment every month or year until death (the "benefit"), in exchange for an initial one-time payment (the "premium").

Q26 This section is going to ask you questions about annuities. Which of the following best describes your current knowledge about this type of product?

1 A lot

2 A little

3 None at all

Q27 Have you purchased an annuity in the private market, for which you are currently receiving or will eventually receive benefits (please exclude all government provided annuities such as your provincial pension plan, the Canada Pension Plan and Old Age Security)?

1 Yes, I have purchased an annuity

2 Yes, I have purchased more than one annuity

3 No

4 Don't know

IF Q27==4(Don't know) GOTO Q28

ELSE IF Q27==3 (No)

Q27a Why haven't you bought an annuity? Choose the main reason.

1 I never thought about buying one, and I have never been offered one (for instance by a

financial advisor).

2 I thought about buying one, but I have not (yet) made a decision.

3 I do not have sufficient savings to purchase one.

4 Such products do not offer good value for money.

5 Such products do not cover my needs.

6 I do not think I will need such a product.

7 I don't know what an annuity is.

8 Other, open...

GOTO Q28

ELSE IF Q27==1,2 (Yes) 
Q27b How did you come to purchase the annuity? If you have purchased more than one annuity, please think about the one you purchased most recently.

1 I was offered an annuity (by my financial advisor, pension plan representative, insurance company, etc.)

2 I searched myself for an annuity

3 Other, open ...

Q27c What was the premium of the annuity (what did you pay)? If you have purchased more than one annuity, please indicate what you paid for the one you purchased most recently.

Numeric $(>\$ 0)$

7777777 Don't know

IF Q27c $==7777777$

Q27d Was it more than \$250,000? 1 Yes 2 No 8888888 Refuse to answer 7777777

Don't know

IF $\mathrm{Q} 27 \mathrm{~d}==1$

Q27e Was it less than \$1,000,000? 1 Yes 2 No 8888888 Refuse to answer

7777777 Don't know

IF $\mathrm{Q} 27 \mathrm{e}==1$

Q28f Was it more than $\$ 500,000$ ? 1 Yes 2 No 8888888 Refuse to answer 7777777 Don't know

END IF

ELSE IF Q27d ==2

Q27g Was it more than $\$ 150,000$ ? 1 Yes 2 No 8888888 Refuse to answer 7777777 Don't know

IF $\mathrm{Q} 27 \mathrm{~g}==2$

Q27h Was it less than $\$ 100,000$ ? 1 Yes 2 No 8888888 Refuse to answer 7777777 Don't know

IF Q27h==1

Q27i Was it more than $\$ 50,000$ ? 1 Yes 2 No 8888888 Refuse to

END IF

answer 7777777 Don't know

END IF

END IF

END IF

Q27j What is the benefit amount the annuity pays out (monthly)? If you have purchased more than one annuity, please indicate the benefit paid by the one you purchased most recently.

Numeric $(>\$ 0)$

7777777 Don't know

IF $\mathrm{Q} 27 \mathrm{j}==7777777$

Q27k Is it more than \$1,000? 1 Yes 2 No 8888888 Refuse to answer 7777777 Don’t know

IF $\mathrm{Q} 27 \mathrm{k}==1$

Q271 Is it less than $\$ 4,000$ ? 1 Yes 2 No 8888888 Refuse to answer 7777777

Don't know

IF Q271 == 1

Q27m Is it more than \$2,000? 1 Yes 2 No 8888888 Refuse to answer 7777777 Don't know

END IF 


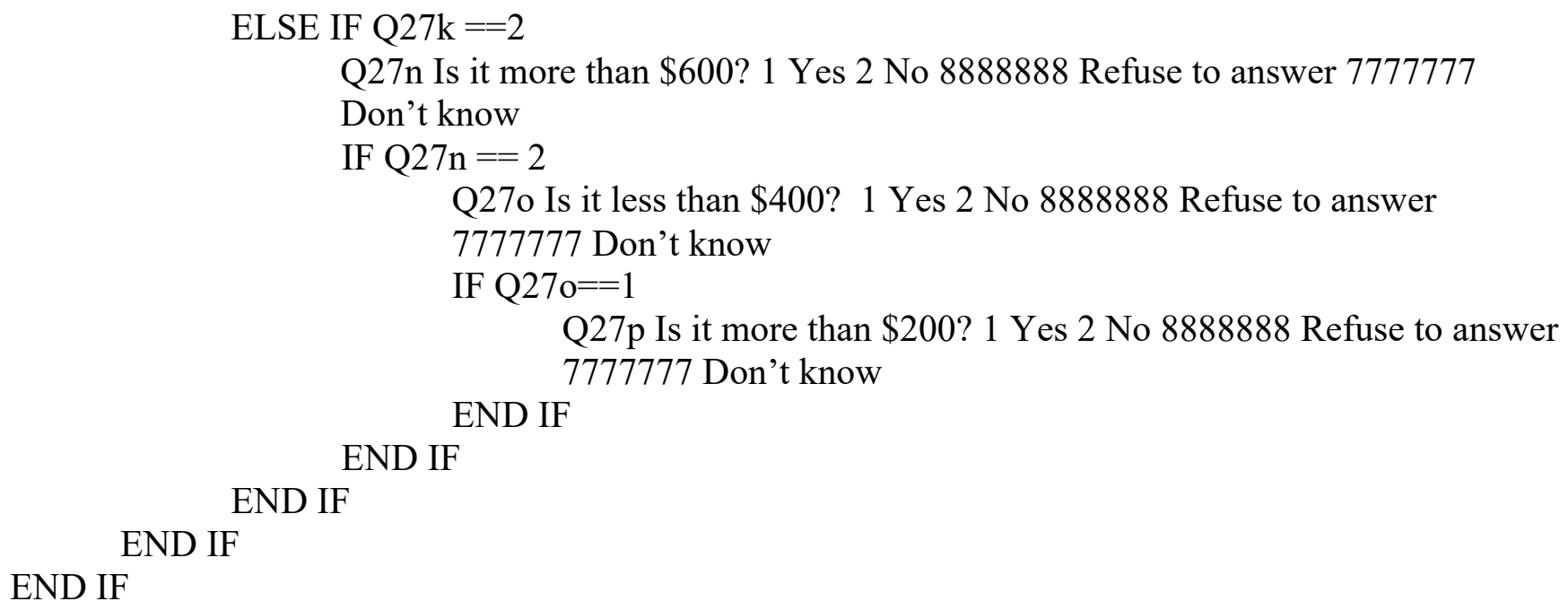

Q28 Do you have life insurance for which you currently pay a premium or that is fully paid and still in force?

1 Yes

2 No

3 Don't Know

IF Q28==1 (Yes)

Q28a What type of life insurance policy do you have?

1 Term life insurance

2 Whole life insurance or Universal life insurance

3 Don't know

4 Other, open...

END IF 


\section{Section 6: Preferences for Annuities [SCENARIOS]}

We are going to show you some simple annuities and ask you to rate them. You can assume that the institution offering the annuity will pay the monthly benefit no matter the circumstances. Once you pay the premium, you receive monthly benefits and have nothing else to pay.

Each product has two attributes:

a) a premium you have to pay;

b) a monthly benefit starting at a given age and lasting until death.

The benefit is adjusted for inflation (indexed).

Q30-34

[SCENARIOS]

What are the chances, $0 \%$ meaning no chance and 100\% meaning for sure, that you would purchase this product if it were offered to you by [a trusted / an] insurance company within the next year?

Numeric (0-100)

$* * * * *$

Randomize [a trusted / an] across individuals with probability 0.5 , and keep constant for each respondent for questions 30-34 (i.e., present all of Q30-34 either with [a trusted] or with [an] for a given individual).

$* * * * *$

Scenarios randomization scheme

Parameters:

Age_benefit $=[($ age +1$), 75,85]$ with probability $[2 / 5,2 / 5,1 / 5]$ where $($ age +1$)=$ the age of the respondent +1

Benefit $=[200,600,1000]$ each with probability $1 / 3$

$$
\begin{gathered}
\operatorname{Load}=[0.5,0.6,0.7,0.8,0.9,1.0,1.1,1.2,1.3,1.4,1.5,1.6,1.7,1.8,1.9,2.0] \\
\text { each with probability } 1 / 16
\end{gathered}
$$

For each combination of Age_benefit and Benefit we provide EPremium, which is the fair premium by age and sex ( 3 × $3=9$ data points; see table attached).

The premium for the contract is given by (please round to nearest $\$ 500$ ):

$$
\text { prem }=\text { EPremium } x \text { Load }
$$

Randomize Age_benefit, Benefit and Load independently (3 x 3 x 16 possibilities) for 5 draws (i.e., each respondent is presented with 5 combinations of Age_benefit, Benefit, and "prem" according to the above probabilities).

Present each draw following this example:

\begin{tabular}{|l|l|}
\hline When you buy the annuity & Starting at age [Age benefit]
\end{tabular}


You pay \$[prem]

You receive \$[Benefit] per month until death, indexed annually for inflation

$* * * * *$ 


\section{FAIR PREMIUMS (VALUES FOR "EPremium")}

For Age_benefit=age+1

\begin{tabular}{rcr}
\multicolumn{3}{c}{ Benefit $=200$} \\
Age & Male & Female \\
$55-59$ & $45,111.40$ & $49,890.91$ \\
$60-64$ & $38,942.44$ & $43,719.50$ \\
$65-69$ & $32,755.36$ & $37,352.10$ \\
$70-75$ & $26,135.90$ & $30,292.54$
\end{tabular}

For Age_benefit $=75$

\begin{tabular}{ccc} 
& \multicolumn{2}{c}{ Benefit $=200$} \\
Age & Male & Female \\
$55-59$ & $13,691.16$ & $17,442.92$ \\
$60-64$ & $15,677.30$ & $19,700.10$ \\
$65-69$ & $18,361.54$ & $22,559.95$ \\
$70-75$ & $22,467.80$ & $26,560.34$ \\
& & \\
For Age_benefit=85 & \\
& & Benefit $=200$ \\
Age & Male & Female \\
$55-59$ & $3,912.57$ & $5,959.01$ \\
$60-64$ & $4,480.15$ & $6,730.13$ \\
$65-69$ & $5,247.24$ & $7,707.14$ \\
$70-75$ & $6,535.00$ & $9,210.44$
\end{tabular}

\begin{tabular}{ccc} 
& \multicolumn{2}{c}{ Benefit $=600$} \\
Age & Male & Female \\
$55-59$ & $135,334.20$ & $149,672.72$ \\
$60-64$ & $116,827.32$ & $131,158.51$ \\
$65-69$ & $98,266.07$ & $112,056.30$ \\
$70-75$ & $78,407.71$ & $90,877.61$
\end{tabular}

Benefit $=600$

$\begin{array}{rcc}\text { Age } & \text { Male } & \text { Female } \\ 55-59 & 41,073.47 & 52,328.77 \\ 60-64 & 47,031.89 & 59,100.30 \\ 65-69 & 55,084.62 & 67,679.85 \\ 70-75 & 67,403.40 & 79,681.01\end{array}$

Benefit $=600$

$\begin{array}{rcc}\text { Age } & \text { Male } & \text { Female } \\ 55-59 & 11,737.70 & 17,877.03 \\ 60-64 & 13,440.45 & 20,190.39 \\ 65-69 & 15,741.71 & 23,121.41 \\ 70-75 & 19,605.01 & 27,631.32\end{array}$

\begin{tabular}{rcc} 
& \multicolumn{2}{c}{ Benefit $=1000$} \\
Age & Male & Female \\
$55-59$ & $225,557.00$ & $249,454.53$ \\
$60-64$ & $194,712.20$ & $218,597.52$ \\
$65-69$ & $163,776.79$ & $186,760.50$ \\
$70-75$ & $130,679.51$ & $151,462.69$
\end{tabular}

\begin{tabular}{ccc} 
& \multicolumn{2}{c}{ Benefit $=1000$} \\
Age & Male & Female \\
$55-59$ & $68,455.79$ & $87,214.61$ \\
$60-64$ & $78,386.48$ & $98,500.51$ \\
$65-69$ & $91,807.70$ & $112,799.74$ \\
$70-75$ & $112,339.00$ & $132,801.69$
\end{tabular}

\begin{tabular}{ccc} 
& \multicolumn{2}{c}{ Benefit $=1000$} \\
Age & Male & Female \\
$55-59$ & $19,562.83$ & $29,795.06$ \\
$60-64$ & $22,400.75$ & $33,650.65$ \\
$65-69$ & $26,236.18$ & $38,535.69$ \\
$70-75$ & $32,675.02$ & $46,052.19$
\end{tabular}

